\title{
LOS ORÍGENES DEL CRISTIANISMO HISPANO. ALGUNAS CLAVES SOCIOLÓGICAS*
}

\author{
POR \\ José FERNÁNDEZ UBIÑA \\ Catedrático de Historia Antigua de la Universidad de Granada
}

\begin{abstract}
RESUMEN
El cristianismo se implantó en Hispania a partir del siglo III, con contenidos y formas de carácter sincretista y entre las oligarquías y capas altas sociales. Por ser estos sectores sus principales difusores y dirigentes, las iglesias hispanas vivieron en plena armonía con su entorno social y asumieron paulatinamente, sin rupturas traumáticas, el papel integrador y político antes desempeñado por la religión romana. La espiritualidad ferviente y libre de las primeras comunidades cristianas sólo se conoció en el siglo IV, entre aristócratas heréticos, perseguidos y marginados por el Estado romano y por la Iglesia ortodoxa.
\end{abstract}

PALABRAS CLAVE: Orígenes del cristianismo, cristianismo hispano

\begin{abstract}
From the third century on Christianity became rooted in Hispania as a syncretic religion that appealed mainly to urban oligarchy and high social strata. Because they were the main Christian disseminators and leaders, the Spanish churches lived in perfect harmony with their social environment and that made it possible for them to assume, without traumatic breaks, the political role and policy of integration previously played by the Roman religion. The first Christian
\end{abstract}

\footnotetext{
*Este trabajo se inscribe en el Proyecto de investigación Diversidad cultural y uniformidad religiosa en la Antigüedad Tardía. La genealogía de la intolerancia cristiana (HUM 2006-11240-C02-02), cofinanciado por el Ministerio de Educación y el Fondo Europeo de Desarrollo Regional. Agradezco muy sinceramente a mis colegas y maestros L. García Moreno, M. Sotomayor y R. Teja las observaciones y sugerencias que me hicieron llegar tras la lectura de un primer borrador de este estudio, aunque los errores que subsistan son del todo responsabilidad mía.
} 
communities' fervent and free spirituality was shared in Hispania especially throughout the fourth century, above all among heretic aristocrats who were relentlessly harassed both by the Roman State and the orthodox Church.

KEY WORDS: Rise of Christianity, Early Christian Spain

Recibido/Received 25-01-2007

Aceptado/Accepted 03-04-2007

Uno de los tópicos más conocidos de nuestra historiografía, ya presente en las crónicas alfonsinas del siglo IX, consideraba que la nación española se forjó con la unidad territorial, política y religiosa del reino visigodo de Toledo, que su legítimo continuador era el reino astur, y que a éste correspondía, por tanto, la misión de restablecer su hegemonía sobre toda la Península, expulsando de la misma a los intrusos musulmanes ${ }^{1}$. Para estos cronistas, la restauración nacional era, pues, una empresa de hondo contenido religioso, por cuanto el cristianismo venía a constituir una especie de rasgo congénito del espíritu nacional español.

Preocupados, sin embargo, por embellecer los siglos y hazañas de la llamada Reconquista, la cristianización primera de España en época romana ocupa un capítulo relativamente marginal en esta historiografía. En tiempos de Felipe II, Ambrosio de Morales era consciente de este desconocimiento sobre la España antigua en general, cosa que él atribuía a que los españoles de los siglos siguientes, absortos en sus luchas contra los moros, «más cuidado tenían de la guerra que de la historia $»^{2}$. En ausencia de fuentes precisas y de una tradición historiográfica rigurosa sobre el tema, la hagiografía más fantasiosa encontró aquí un campo propicio para su desarrollo. De este modo, las vidas de santos y mártires, algunos instruidos directamente por Jesús o enviados por los primeros apóstoles, y la proliferación de falsos cronicones en los siglos XVI y XVII suplieron con creces la escasez de testimonios fidedignos sobre la cristianización de España ${ }^{3}$.

Como es sabido, en esta literatura fantástica se han basado las tradiciones más populares sobre los orígenes del cristianismo peninsular, algunas de la cuales conservan todavía un sorprendente arraigo. Es algo comprensible, si tenemos en cuenta que el tema sólo se planteó de manera crítica ya entrado el si-

\footnotetext{
${ }^{1}$ Cfr. A. Barbero y M. Vigil, La formación del feudalismo en la Península Ibérica, Barcelona 1978,232 ss.

${ }^{2}$ Más detalles y referencias sobre esa historiografía en J. FERnÁndeZ UBIÑA, «Clasicismo y fin del Mundo Antiguo en la historiografía española moderna y contemporánea», en Ma J. HidALGO, D. PéreZ D. y M. J. R. GERVÁs (eds), «Romanización» y «Reconquista» en la Península Ibérica: nuevas perspectivas, Salamanca 1998, pp. 191-213.

${ }^{3}$ El estudio clásico sobre la materia es el de J. Godoy AlCántara, Historia crítica de los falsos cronicones, Madrid 1868 (ed. facsímil con estudio preliminar de Ofelia Rey Castelao, Granada 1999). Cfr. además J. CARO BAROJA, Las falsificaciones de la Historia (en relación con la de España), Barcelona 1992, pp. 97 ss.
}

Hispania Sacra, LIX

120, julio-diciembre 2007, 427-458, ISSN: 0018-215-X 
glo XX, y el peso de la leyenda aún se deja sentir, al menos, en dos presupuestos teóricos que carecen, a mi juicio, de todo fundamento: el primero es la percepción del cristianismo primitivo como una doctrina sublime difundida por hombres santos que lucharon incansablemente en un entorno adverso, degenerado y decadente, hasta lograr al fin su cristianización. El segundo presupuesto es dar por sentado, de manera más o menos matizada, que la nueva religión llegó a España en época temprana y desde un lugar preciso, preferentemente Cartago o Roma, y que esta procedencia geográfica determinó el desarrollo y rasgos espirituales de las iglesias hispanas en los siglos siguientes.

El objetivo de estas páginas no es otro que replantear sobre presupuestos históricos esta problemática y destacar en particular la dimensión sociológica de la misma, pues creo que es en ella donde están las claves esenciales para entender cómo y de qué modo se cristianizó Hispania.

\section{ORÍGNES LEGENDARIOS DEL CRISTIANISMO HISPANO}

Sorprendidos por las escasas, cuando no nulas noticias acerca de la misión de la mayoría de los Apóstoles, ya en la Antigüedad surgieron numerosas leyendas que convertían a todos y cada uno de ellos en heroicos y eficaces difusores de la fe, tanto dentro como fuera de los límites del Imperio romano. Estos relatos legendarios sobre la vida y hechos de los Apóstoles colmaron la curiosidad ingenua y piadosa de los primeros fieles, y conformaron uno de los géneros más populares de la literatura cristiana ${ }^{4}$. En Occidente, sin embargo, no abundaron ni arraigaron leyendas de este tipo en los primeros siglos del cristianismo, posiblemente porque desde muy pronto se aceptó por doquier la tradición (legendaria en sentido estricto) de que Pedro fue el fundador de la iglesia de Roma y el único apóstol de Occidente, excepción hecha del viaje y estancia de Pablo en la capital del Imperio (esta vez histórica, a la luz de Hechos de los Apóstoles 27-28). La apostolicidad exclusiva de Roma será, por lo demás, enérgicamente defendida y propalada por el papado romano como argumento decisivo para justificar su primacía espiritual sobre todo el orbe cristiano y muy en especial sobre las regiones occidentales ${ }^{5}$.

${ }^{4}$ Los relatos más importantes de este género -los Hechos de Andrés, Juan, Pedro, Pablo y Tomáshan sido al fin editados y traducidos al español por Antonio Piñero y Gonzalo del Cerro en la Biblioteca de Autores Cristianos: Hechos apócrifos de los apóstoles, 2 vols. Madrid 2004 y 2005 (n 646 y 656). Los autores anuncian en el prólogo al vol. I una futura publicación que recogerá los Hechos de Felipe, Matías (Mateo), Bartolomé, Tadeo y otros apóstoles.

${ }^{5}$ Así lo deja ver con claridad el papa Inocencio I en la carta que dirigió el año 416 al obispo Decencio de Gubbio (PL 20, 552), donde afirma que en Italia, Francia, Hispania, África, Sicilia e islas intermedias sólo fundaron iglesias Pedro y sus sucesores. A finales de este siglo V también el papa Gela 
Se entiende así que las leyendas sobre una supuesta evangelización apostólica de Hispania sean tardías y que en su mayoría no dejen por ello de reconocer el primado romano, petrino y paulino. Cuando no es así, por principio hay que sospechar en los gestores y beneficiarios de estas leyendas algún problema con Roma. Dado, en fin, que todas ellas sólo pretenden magnificar los inicios del cristianismo hispano con un sello de apostolicidad directa, apenas nada históricamente fiable cabe esperar de estas narraciones o que aporte luz alguna sobre los orígenes históricos del cristianismo peninsular, por más que numerosos eruditos hayan intentado probar lo contrario durante los últimos siglos. Es bien sabido, por contra, que la ausencia de testimonios históricos fidedignos fue más un acicate que un impedimento para las imaginativas mentes del Medioevo, que pudieron recrear libremente estos orígenes, adaptarlos a los gustos de su propia época y, sobre todo, reconstruir a su antojo un glorioso origen apostólico para innumerables iglesias locales.

La leyenda más antigua tuvo como héroe principal a Santiago el Mayor, hijo del Zebedeo, apóstol decapitado en Jerusalén, por orden de Herodes Agripa, el año 44 (Hch 12, 1 ss.). Bastaría sólo esta fecha de su muerte para quitar toda credibilidad a la hipótesis de que él fuera el primer evangelizador de Hispania, pues apenas habría contado con unos pocos años para cumplir tamaña misión, en una tierra tan lejana y con una población cuya lengua y costumbres desconocía. El principal argumento en su contra es, sin embargo, que nada diga al respecto la literatura hispana o gala antes del siglo VII, ni siquiera la de Galicia, tierra en la que más arraigo tendría la leyenda hasta el punto de que una variante posterior de la misma afirma que el cuerpo sin vida de Santiago fue milagrosamente transportado desde Jerusalén y enterrado en Santiago de Compostela, que a ello debe su nombre 6 .

Las leyendas sobre la predicación de Santiago en Hispania, como las referentes a su translatio y a la inventio de su sepulcro en Galicia, nada aportan sobre los orígenes reales del cristianismo en la Península ibérica, y su estudio, en consecuencia, deben hacerlo los medievalistas en relación con la conquista de Hispania por ejércitos fieles al Islam (por entonces más bien considerado una herejía de corte arriano), con la difusión del adopcionismo entre las iglesias

sio dejó escrito su convencimiento de que Pablo no vino a Hispania (Ep. 97, 67 (CSEL 35, I, 427) y Ep. 103, 24 (CSEL 35, I, 483).

${ }^{6}$ Entre la numerosa bibliografía sobre el tema cabe recordar los estudios ya clásicos de L. DuchesNE, «Saint Jacques en Galice», en Annales du Midi 12 (1900), 145-179 y C. SÁNCHEZ AlboRnOZ, «En los albores del culto jacobeo», en Compostellanum 16 (1971), 37-71. Cfr. además la reciente actualización documental y bibliográfica de M. SOTOMAYOR, «La llegada del cristianismo a la Península: datos históricos y explicaciones tardías», en E. MuÑIz y R. URÍAs (eds), Del coliseo al Vaticano. Claves del cristianismo primitivo, Sevilla 2005, pp. 213-231, esp. 221 ss. y sobre todo O. Rey CASTELAO, Los mitos del apóstol Santiago, Vigo 2006.

Hispania Sacra, LIX

120, julio-diciembre 2007, 427-458, ISSN: 0018-215-X 
mozárabes hispanas capitaneadas por el metropolita de Toledo y, en fin, con la reacción militar anti-islamista iniciada en el norte peninsular, que pronto vio en Santiago su santo protector, símbolo de la ortodoxia católica y patrono incluso de los incipientes reinos cristianos.

Con similar criterio histórico deben estudiarse las leyendas relativas a los siete varones apostólicos, si bien en ellas, pace García Moreno, no se percibe sentimiento alguno de distanciamiento o independencia respecto al primado romano ${ }^{7}$. Más bien al contrario, a estos míticos varones se les supone ordenados obispos en Roma por Pedro y Pablo (los «santos apóstoles» suele decirse) y enviados a evangelizar Hispania. Conducidos por Dios, desembarcaron en las costas del sur y se asentaron inicialmente en Acci, actual Guadix (Granada). Tras algunos percances y éxitos misioneros, los siete se dispersaron y vinieron a establecerse en sendas ciudades del sur y sureste peninsular, de las que todavía hoy siguen siendo patronos populares ${ }^{8}$. Aunque algunos historiadores han visto en estas actas, redactadas probablemente a mediados del siglo VIII, la huella de una tradición auténtica o un testimonio indirecto de que el cristianismo penetró por el sur hispano debido a su origen norteafricano ${ }^{9}$, lo cierto es que en ellas nada hay fiable que pruebe tal cosa, menos aún la llegada del cristianismo en fechas tan tempranas. Curiosamente, estas leyendas apostólicas suponen, en cierto modo, negar la venida de Pablo a Hispania, venida que, si bien es más que dudosa, tiene al menos en su favor que el propio Pablo dejó escrito su deseo de difundir sus doctrinas en esta tierra del extremo occidente no sin antes pasar por Roma (Rom 15, 22-29) ${ }^{10}$.

Si nada fiable dicen sobre la primera cristianización de la Península, todas estas leyendas nos interesan, en cambio, porque vienen a confirmar que ya en el siglo VIII el cristianismo católico se configuró como la principal referencia

\footnotetext{
${ }^{7}$ Luis A. García Moreno, que tan a fondo conoce la literatura y la historia altomedieval, apuntaba recientemente la hipótesis de que la leyenda fuera un intento de la iglesia mozárabe hispana por poner a sus obispos a la misma altura que el papado en cuanto a raíces apostólicas y de potestad espiritual, a finales del siglo VIII ( «San Torcuato y sus compañeros. Los orígenes de una leyenda», en Europa (Universidad Nacional de Cuyo. Facultad de Filosofía y Letras), 0 (2000), 23-40). Cfr. Además, de este mismo autor, «La Iglesia en la España visigoda y postvisigoda. Obispos y santos», en J. ANDRÉs GALLEGO (ed.), La historia de la Iglesia en España y el mundo hispánico, Murcia 2001, pp. 91-120.

8 J. VIVES, «La Vita Torquati et comitum», en Analecta Sacra Tarraconensia, 14 (1941), 31-58; A. FÁbregas Grau, Pasionario hispánico, Madrid-Barcelona 1953, pp. 125-130; P. RIEsCo, Pasionario hispánico, Sevilla1995, pp. 130-139.

${ }^{9}$ Así, entre otros, Manuel ToRres en su capítulo sobre «La Iglesia en la España romana» de la Historia de España dirigida por R. Menéndez Pidal, Madrid 1935, pp. 447-486, esp. p. 450; y E. SÁNCHEZ SALOR, «Los orígenes del Cristianismo en Hispania. Los casos de Mérida y León-Astorga», en Estudios de Religión y Mito en Grecia y Roma, León 1995, pp. 165-181, esp. 166.

${ }^{10}$ Las principales fuentes históricas sobre tan problemático viaje paulino y las discrepantes valoraciones de la historiografía moderna pueden verse en M. SOTOMAYOR, Historia de la Iglesia en España, Madrid 1979, 159 ss.
} 
identitaria de los reinos norteños frente al invasor musulmán, a la sazón dueño de casi toda la vieja Hispania. Es una verdad más que sabida, pero conviene subrayar que esta identidad, aunque proyectada hacia un remoto origen apostólico, se inspira realmente en el cristianismo altomedieval, al que espontáneamente se supone dotado de una compleja jerarquía (con Roma a la cabeza del episcopado), un dogma doctrinal y rituales elaborados, y, lo que es más importante, dotado con un poder sobrenatural para imponerse ante enemigos (musulmanes) y extraños (como los paganos de Acci) más recurriendo a las armas y a la violencia que a los argumentos y al ejemplo moral de los primeros cristianos. En otras palabras, ni estas leyendas, ni los fieles que las creyeron, tuvieron una idea cabal del cristianismo de los primeros siglos, sino de aquel que en los albores de la Edad Media se difundía e imponía por deseo divino y era, en consecuencia, el principal sostén de los nuevos Estados peninsulares, los artífices de la mitificada Reconquista.

Resulta, pues, lógico que cuando esta Reconquista culminó en 1492 con la toma de Granada, y en los decenios siguientes se planteó el espinoso problema de la integración de los musulmanes vencidos, especialmente de los indómitos moriscos, adquiriese una fuerza renovada la leyenda de los varones apostólicos, que venía a justificar el origen y esencia cristiana del embrionario Estado español y el carácter intruso y postizo del Islam. Que en esta nueva versión de la leyenda, los principales Varones apostólicos -Cecilio y Tesifonte- sean de estirpe árabe y discípulos de Santiago muestra hasta qué punto era necesario, en la Granada de la época, distinguir entre raza (árabes o moriscos que buscan la integración, manteniendo sus señas de identidad cultural) y religión islámica (de tan difícil aceptación por aquella sociedad cristiana y contrarreformista). En este clima de recuperaciones identitarias y de conflictos religiosos entendemos hoy la rocambolesca historia de los fraudes del Sacromonte, de los libros plúmbeos y de las reliquias martiriales allí aparecidas en los años finales del siglo XVI e inicios del XVII ${ }^{11}$.

En un contexto similar -el de la búsqueda contrarreformista de gloriosos orígenes apostólicos y martiriales para el catolicismo español frente a las innovaciones de la Reforma protestante- se explica el extraordinario florecimiento de textos pseudohagiográficos y de falsos cronicones antes mencionados, en los que quedaba fuera de toda duda la venida de Santiago y de otros apóstoles a España, y el carácter inequívocamente católico de las esencias patrias. El clima social y mental favorable a este tipo de narraciones se pone de relieve no sólo

\footnotetext{
${ }^{11}$ Cfr. sobre este tema, F. J. Martínez Medina, San Gregorio y San Cecilio. Historia y tradiciones sobre los orígenes del cristianismo en Granada, Granada 1997, esp. pp. 19 ss. M. BARRIOS AGUILERA, Los falsos cronicones contra la historia (o Granada, corona martirial), Granada 2004, esp. pp. 23 ss. Idem, «Las invenciones del Sacromonte. Estado de las cuestiones y últimas propuestas», en I. GómEZ DE Liaño, Los juegos del Sacromonte. Edición facsímil, Granada 2005, pp. VII-LIII.
}

Hispania Sacra, LIX

120, julio-diciembre 2007, 427-458, ISSN: 0018-215-X 
en su calurosa acogida por masas o clérigos incultos o sabiamente interesados, sino también por espíritus preclaros de la época, siendo entonces abiertamente marginados los pocos que osaron poner freno a tantas patrañas. De hecho, la investigación sobre los orígenes del cristianismo en España se ha visto lastrada por esta fuerte tradición oscurantista hasta bien entrado el siglo XX y su influencia es todavía hoy visible en los estudios de corte más conservador sobre la materia ${ }^{12}$. Lo que más interesa al propósito de estas páginas es que semejante visión histórica ha impedido un análisis sociológico correcto de la difusión del cristianismo en la Península, pues ni siquiera se ha tenido en cuenta, como veremos en seguida, que esta religión conoció una transformación tan profunda en sus dos primeros siglos de existencia que apenas quedó nada en ella de su prístino carácter judaizante, petrino o paulino. Es particularmente necesario subrayar esta metamorfosis del cristianismo cuando estudiamos su difusión por Hispania, pues lo cierto es, en palabras de Guignebert, que «en rigor, los occidentales jamás han sido cristianos» ${ }^{13}$.

\section{LOS PRIMEROS TESTIMONIOS HISTÓRICOS}

Por haberse idealizado de tal modo el origen del cristianismo hispano, no sorprende que los primeros datos históricos sobre el mismo -la carta 67 de Cipriano y las actas del concilio de Elvira- fueran a menudo vistos con despectivo recelo, pues en ellos queda patente que la moral y la fe de los primeros cristianos, tanto de la jerarquía como de la grey, estaban lejos de ser ejemplares. Hasta muy avanzado el siglo XX ni siquiera faltaron estudiosos españoles, todos vinculados de algún modo a la Iglesia católica y de hondo espíritu tradicionalista, que se negaban a aceptar la imagen de las primeras comunidades hispanas transmitida por la citada carta de Cipriano, y optaban con indisimulado despecho por considerarla una burda falsificación ${ }^{14}$. Con más vigor y desazón, si

12 Excelente visión de síntesis en M. SotomaYor, «La llegada del cristianismo a la Península...» op. cit. esp. 226 ss. Un caso ilustrativo de este oscurantismo historiográfico lo proporciona la diócesis de Jaén, que ocupó un lugar privilegiado en los falsos cronicones y dio origen a una riquísima y fantástica producción hagiográfica, como recientemente ha puesto de relieve P. CASTILLO MALDONADO, La primera cristianización de Jaén: historia eclesiástica (ss. IV-IX), Jaén 2005, esp. 15 ss.

13 C. Guignebert, El cristianismo antiguo, México 1983, p. 206 (primera edición francesa de 1921)

14 A. QuintanA, «La cristianización de Astorga», en Actas del I Congreso Int. Astorga Romana, Astorga 1986,pp. 91 ss. con las observaciones críticas de R. TEJA, «Mérida cristiana en el siglo III: sus primeros obispos», en Mérida y Santa Eulalia, Mérida 1993, pp. 33-44, esp. pp. 35-36 y n. 2. Recordemos que en esta carta Cipriano alude a los obispos de Mérida y León-Astorga, que depusieron sus cargos tras apostatar durante la persecución de Decio, pero años después, con el visto bueno del papa Esteban, reivindicaron sus respectivas cátedras episcopales. Fue entonces cuando los obispos que ha- 
cabe, la historiografía española ha puesto en duda la fiabilidad de las actas del concilio de Elvira y hasta la ortodoxia de algunos de sus cánones, algo que ya en el siglo XVI exasperaba a uno de sus principales valedores, Fernando de Mendoza, al que debemos uno de los mejores y, paradójicamente, menos conocidos estudios sobre el concilio iliberritano ${ }^{15}$.

Téngase presente que en estas fechas se daba por supuesto que el cristianismo, encarnado en una Iglesia eterna, era una Verdad absoluta que se había mantenido intacta desde sus orígenes, e intacta se mantendría hasta el final de los tiempos. Todo cambio o desviación era obra de herejes. De ahí que Mendoza, como otros estudiosos posteriores, ni percibiera ni aceptara evolución o cambio de ningún género entre las enseñanzas de los apóstoles y la doctrina aprobada en Elvira. Lo único que cambia, para fieles como él, es el ambiente social en que vive y al que a veces debe adaptarse la Iglesia con el objetivo final de su cristianización. Sólo desde esta perspectiva, que subordina la historia política a la religiosa, o admitiendo que los concilios provinciales no convocados por el papa podían caer en errores, algunos sabios católicos, como Melchor Cano o Baronio, pudieron ya entonces criticar algunas medidas iliberritanas, sobre todo la tendencia iconoclasta del canon $36^{16}$. Pero era demasiado obvio que el conjunto de sus actas distaba mucho y en puntos esenciales de las formas de vida religiosa propia de las comunidades primitivas. Esta contradicción fue, además, tendenciosamente resaltada por el antiespañolismo manifiesto de numerosos eruditos europeos, que avalaban con estos primeros testimonios históricos sus viejos prejuicios sobre el carácter mundano, ceremonial y fanático del cristianismo español. En esta contemplación despectiva vinieron a coincidir, al menos desde el siglo XVIII, tanto los estudiosos de inspiración protestante, entre los que destacarán Dale y Harnack, como algunos católicos de la vecina y no siempre amiga Francia, con Leclercq y Duchesne como figuras destacadas ${ }^{17}$.

bían reemplazado a estos apóstatas, junto a un puñado de fieles, pidieron consejo a Cipriano. Éste, en la carta citada (que recoge el sentir de un sínodo cartaginés), les da la razón y niega a los obispos apóstatas todo derecho a reingresar en la clericatura.

15 A. Díaz Toledo, «El concilio de Elvira a la luz de Fernando de Mendoza», en Sodalitas, 3 (1983), 109-123, y la encomiable investigación de T. Berdugo Villena, Fernando de Mendoza. De confirmando concilio Illiberritano (Libro I). Texto, traducción y notas. Tesis doctoral, inédita, leída el 14 de enero de 2005 en la Universidad de Granada.

${ }^{16}$ Dada la atmósfera de suma tensión religiosa y política en que vive España a finales del siglo XVI e inicios del XVII, se entiende que Fernando DE MENDOZa (Sobre la defensa y aprobación del Concilio Illiberritano, Madrid 1593, p. 227) asegurara que el estudio de este concilio suponía una «arriesgada dificultad», a la que decide hacer frente incitado por «el amor a la patria, la razón de la piedad y el celo de la religión».

${ }^{17}$ El más torpe de todos ellos fue, con diferencia, H. LeCLerCQ, L'Espagne Chrétienne, Paris, ${ }^{2} 1906$, obra de la que hizo una precisa valoración la comedida crítica de H. Delehaye (AB, 25, 1906, 104). Cfr. Otras referencias en R. TEJA, «Una mirada a los estudios sobre el cristianismo antiguo en España», en AA. VV, Revisiones de Historia Antigua III. El cristianismo. Aspectos históricos de su origen y difusión

Hispania Sacra, LIX

120, julio-diciembre 2007, 427-458, ISSN: 0018-215-X 
La idealización religiosa y la exaltación nacionalista no aportaron nada, salvo oscurantismo, al conocimiento del cristianismo primitivo en Hispania, pues daban por verídicos e incuestionables los relatos transmitidos en las leyendas apostólicas y su interés no era, al cabo, sino magnificar (o denigrar) la Iglesia y la Patria española. Aunque estos prejuicios se pueden dar hoy por superados, su eco es todavía perceptible en el enfoque, inconscientemente idealizador, con el que a menudo se aborda el complejo y escasamente documentado problema de los orígenes del cristianismo hispano. Me refiero, en primer lugar, a la creencia de que el cristianismo se difundió en épocas muy tempranas, antes de mediados del siglo II, por la Península, y, en segundo lugar, a la equiparación inconsciente que suele hacerse entre este cristianismo hispano y el que vivieron y difundieron las primeras comunidades.

Lo cierto es, sin embargo, que, en tanto nuevos testimonios no digan lo contrario, hemos de aceptar que la cristianización de Hispania se produjo en fechas tardías, no antes del siglo III y que, en consecuencia, se trataba de una religión ya muy romanizada. Es importante destacar este extremo porque ello nos obliga a tener en cuenta que Hispania no conoció, que sepamos, ninguna de las formas primigenias del cristianismo, como tampoco lo conoció ninguna provincia de la parte occidental del Imperio, con excepción de Roma y quizá de alguna otra ciudad donde pudieron coincidir un puñado de fieles de los que no nos ha llegado ningún testimonio histórico ${ }^{18}$. Conviene tener presente que el cristianismo de los siglos I y II era una creencia plural, fragmentada en corrientes e iglesias heterogéneas y no siempre bien avenidas, y que sus adeptos constituían una exigua minoría, apenas unas decenas de miles de fieles desigualmente repartidos por las innumerables ciudades del Imperio y liderados por unas docenas de

en Hispania, Vitoria 2000, pp. 29-36, y P. CASTILlo MALDONADO, «Contribución a la historiografía del cristianismo hispano de la Antigüedad tardía: anotaciones marginales en un medio jesuítico a L'Espagne chrétienne (Lecoffre, Paris, ${ }^{2}$ 1906), de Dom H. Leclercq», en Hispania Sacra 120 (2007), 613-631.

18 Es, obviamente, muy probable que algún cristiano aislado viajara o viviera en la Península ya en el siglo I o incluso que se formara alguna pequeña comunidad que no ha dejado rastro histórico. Máxime si tenemos en cuenta que en esos primeros decenios las diferencias entre judaísmo y cristianismo son confusas. Pero lo que aquí se estudia es la implantación de esta religión en sectores sociales suficientemente amplios e influyentes para dejar su impronta testimonial en la sociedad de su tiempo. En este sentido, la referencia más antigua la transmiten Ireneo de Lyon (Adv. Haer. I, 13, 1 ss.) y Jerónimo (Ep. 75, 3), que atestiguan la llegada a Hispania, a mediados del siglo II, de un tal Marcos, discípulo del gnóstico Basílides, quien tuvo al parecer gran éxito entre mujeres de noble alcurnia a las que engatusó con artes mágicas y secretos placeres corporales. Desgraciadamente, esto es todo lo que sabemos. Para el siglo siguiente, cfr. H. CHADwICK, «The Church of the Third Century in the West», en A. KING y G. M. HeNIG (eds.), The Roman West in the Third Century. Contribution from Archaeology and History, Oxford 1981, pp. 5-13. A pesar del título, Chadwick habla más de las iglesias orientales que de las occidentales, de las que hay poquísima documentación en el siglo III, con la excepción de África y Roma. 
hombres letrados o carismáticos ${ }^{19}$. Lo milagroso es que al fin lograran forjar una sólida unidad en torno a una sola y Gran Iglesia a finales del siglo II e inicios del III. No es, por tanto, sorprendente que en Hispania no haya el más mínimo rastro de judeocristianismo, es decir, del cristianismo entendido como una secta judía que tiene a Jesús por profeta o mesías, pero no Dios, y espera anhelante la llegada inmediata de su Reino; ni tampoco sorprende que las fuentes desconozcan la presencia en la Península del ideario teológico y sacramental difundido por Pablo y sus seguidores, con sus esperanzas escatológicas y su organización en iglesias autónomas y fraternales; ni que tampoco atestigüen la presencia en las provincias hispanas del cristianismo filosófico y moralizante que difundieron los apologetas griegos del siglo II $^{20}$.

De lo que nos hablan los primeros testimonios hispanos es, por contra, de una religión jerárquicamente estructurada, muy compenetrada con su entorno social y religioso, y también muy desigualmente implantada por la Península ibérica. Es obvio que esta religión y la mayoría de sus seguidores no constituían un revulsivo espiritual entre sus coetáneos, ni su limitado atractivo anunciaba el triunfo espectacular que le esperaba a lo largo del siglo IV. Lo veremos enseguida mediante el análisis -si bien sucinto por ser un material bien conocidode los dos principales testimonios antes mencionados: la carta 67 de Cipriano y los cánones de concilio de Elvira.

Lo que pretendo hacer no es valorar sus contenidos a la luz de lo que nosotros entendemos hoy por cristianismo, pues es precisamente este enfoque metodológico el que ha llevado a las conclusiones sesgadas -negativas o positivassobre los contenidos religiosos de estos textos y sobre la altura o vulgaridad espiritual del cristianismo español en general. Mi lectura pretenderá ignorar cualquier concepción apriorística de lo que debe ser el cristianismo y evitar en consecuencia toda comparación o conclusión de carácter moral, destacando tan solo cómo veían sus seguidores esta religión, cómo incidía en sus vidas y, en

${ }^{19}$ Sugerentes y sutiles, aunque a veces erráticas, son las observaciones sobre la expansión del cristianismo, su teórica progresión matemática y el papel peculiar de sus dirigentes, desarrolladas por K. HopkINS, «Christian Number and Its Implications», Journal of Early Christian Studies 6,2 (1998), 185226; Idem, A World full of Gods. The Strange Triumph of Christianity, Nueva York 2001, 82 ss. 121 ss. Sobre la diversidad de corrientes judías y cristianas del siglo I e inicios del II puede verse un excelente estado de la cuestión en J. D. G. Dunn (ed.), Jews and Christians. The Parting of the Ways AD 70 to 135, Cambridge 1999.

${ }^{20}$ Sobre estas diversas formas de cristianismo se ha publicado en los últimos años un número literalmente inabarcable de obras. De lo que conozco, me parecen especialmente clarificadores para el tema que nos ocupa el estudio de M. SACHOT, La invención de Cristo. Génesis de una religión, Madrid 1998 y los diferentes trabajos de corte histórico incluidos en la obra de P. F. EsLER (ed.), The Early Christian World, 2 vols. Londres 2000. Una visión de síntesis puede encontrarse en J. FERNÁNDEZ UBIÑA, «El cristianismo greco-romano», en M. SOTOMAYOR y J. FERnÁNDEZ UBIÑa (coords.), Historia del cristianismo I. El mundo antiguo, Madrid 2006, 227-291, esp. pp. 229 ss.

Hispania Sacra, LIX

120, julio-diciembre 2007, 427-458, ISSN: 0018-215-X 
fin, cómo era percibida por su entorno social. ¿No es así como se aborda el estudio de las demás religiones? Para alcanzar este propósito será suficiente, creo, analizar solamente dos aspectos: 1) el comportamiento de los clérigos, de los que cabe esperar una mayor concienciación y formación religiosa, y 2) las peculiaridades de las creencias y prácticas cristianas, en relación, claro está, con las ideas religiosas dominantes en la Hispania romana de esa época.

\subsection{Los clérigos hispanos preconstantinianos}

Si algo resulta llamativo en la jerarquía cristiana de este tiempo es la naturalidad con que los fieles hispanos asumían y desempeñaban los diversos cargos clericales. Es obvio que ello no implicaba ninguna ruptura ni con su carrera política, ni con su actividad social, ni con su vida familiar. No se advierte ninguna renuncia a la manera de los primeros apóstoles o de clérigos excepcionales como Ambrosio o Agustín. Se puede suponer que hubo casos de este tipo, de hombres y mujeres que cambiaran radicalmente de vida al entrar en la clericatura o simplemente tras su conversión, pero las fuentes no los documentan en Hispania. Desde luego, nada sabemos al respecto del papel desempeñado por la mujer, por lo que hemos de pensar que ninguna accedió a los órdenes mayores del clero, y es dudoso que ocuparan un papel significativo en otros ámbitos de la jerarquía eclesiástica. Ni siquiera se menciona a las viudas, que durante algún tiempo jugaron un papel destacado en algunas iglesias de Oriente y Occidente. El concilio de Elvira alude a dos tipos de vírgenes, unas consagradas a Dios (can. 13), y otras que son simples célibes que guardan castidad sin compromisos religiosos de mayor alcance (can. 14). Y en ambos casos el concilio se refiere a ellas para censurar sus tropiezos sexuales, que condena con rigor. La clericatura hispana, por tanto, fue desde sus orígenes patrimonio de hombres.

Los obispos más antiguos de los que tenemos noticia en Hispania, Marcial de León-Astorga y Basílides de Mérida ${ }^{21}$, vivían plenamente inmersos en la vida social y religiosa de sus respectivas ciudades. Ningún conflicto tuvieron con el entorno gentil o «pagano»22, con el que, por contra, mantenían excelen-

${ }^{21}$ Aunque a menudo se ha pensado lo contrario, creo convincentes los argumentos sobre la vinculación de Basílides a Mérida y de Marcial a León-Astorga esgrimidos por G. W. CLARKE («Prosopographical Notes on the Epistles of Cyprian. I. The Spanish Bishops of Epistle 67», en Latomus 30 (1971), 1141-45. Idem, The Letters of St Cyprian of Carthage (Ancient Christian Writers, 47), New York 1989, vol. IV, 139-158) y R. TEJA, («La carta 67 de S. Cipriano a las comunidades cristianas de León-Astorga y Mérida: algunos problemas y soluciones», en Antigüedad y Cristianismo, VII (1990), 115-124).

${ }^{22}$ El término «pagano» se generaliza, con sus connotaciones negativas, en fechas tardías, de modo que aquí lo empleo con un valor meramente descriptivo. Cipriano utiliza el vocablo latino gentiles para designar a los no cristianos. 
tes relaciones. Tanto que es difícil imaginar en qué disentían, salvo en la celebración de rituales propios (bautismo y eucaristía) o de alguna festividad. Estas disidencias hay que suponerlas, porque la carta 67 de Cipriano, escrita probablemente en el otoño del año 254, lo que destaca es, por el contrario, que ambos compartían sin reservas las costumbres romanas. Lo grave, como apunta el obispo cartaginés, no es tan sólo que rindieran voluntariamente sacrificio a los dioses cuando así lo pidió el emperador Decio el año 250. A ello se añadía que ya antes formaba parte Marcial de un collegium, participaba en «banquetes vergonzosos» y enterraba a sus hijos en cementerios paganos y a la manera de los paganos (Cip. Ep. 67, VI, 1-2). Todo esto implicaba participar activamente en rituales politeístas. Basílides, por su parte, lejos de acentuar su fe y el miedo al Infierno cuando se encontraba enfermo, maldijo en esta situación a Cristo, lo que equivale a reconocer su apego a los cultos tradicionales. A todo ello parece aludir Cipriano cuando los considera culpables de «crímenes nefandos» $(E p .67, \mathrm{I}, 1)^{23}$.

Aunque ya era una tradición disciplinaria de la Iglesia que los clérigos apóstatas abandonaran irrevocablemente sus cargos y cumplieran la debida penitencia como laicos, en este caso no es seguro que Basílides lo hiciese. Cipriano asegura que depuso espontáneamente el episcopado, no como consecuencia directa de su apostasía, sino por el remordimiento que le causó haber blasfemado contra Dios cuando estaba enfermo. Cabe pensar, no obstante, que su renuncia pudo estar en gran medida condicionada por la presión de parte de la comunidad emeritense y de algunos clérigos de la ciudad y del entorno geográfico, todos los cuales nombraron en su lugar a Sabino. Pero los partidarios de Basílides debían de tener una fuerza mayor y consiguieron reponerlo como obispo tras apelar con éxito al papa Esteban ${ }^{24}$.

No compete al historiador calibrar la pureza mayor o menor de una y otra facción, pues, como queda dicho, ello nos llevaría a valoraciones espirituales que, por su subjetividad, más contribuirían a confundir que a clarificar el pro-

${ }^{23}$ Conviene recordar que desde inicios del siglo II algunos gobernadores provinciales condenaban a muerte a los cristianos por el mero hecho de serlo, dejándolos consecuentemente en libertad si probaban, ofreciendo sacrificios y maldiciendo a Cristo, que no lo eran. Sobre este aspecto el más antiguo y mejor ejemplo lo encontramos en Plinio el Joven (Ep. 10.96, 10), y el mejor estudio en G. de STE CROIX, «Las persecuciones. El choque del cristianismo con el gobierno imperial romano», en A. ToYNBEE (ed.), El crisol del cristianismo, Madrid 1988, 492-519; Idem, «¿Por qué fueron perseguidos los primeros cristianos?», en M. I. FINLEY (ed.), Estudios sobre historia antigua, Madrid 1981, pp. 233 273. Dados los numerosos errores de esta traducción castellana, es recomendable leer este trabajo en su versión original inglesa (Past and Present, 26, 1963, págs. 6-38), ahora reproducida, con breves actualizaciones bibliográficas, en Idem, Christian Persecution, Martyrdom, and Orthodoxy, editado por M. Whitby y J. STREeTER, Oxford 2006, pp. 105-152.

${ }^{24}$ Cipriano, Ep. 67, V, 2-3. Esta apelación de Basílides a Roma es la primera de la que se tiene testimonios histórico, según A. von HARNACK, Missione e propagazione del Cristianesimo nei primi tre secoli, Cosenza 1986, p. 539.

Hispania Sacra, LIX

120, julio-diciembre 2007, 427-458, ISSN: 0018-215-X 
blema, máxime cuando sólo conocemos la versión de una de las partes. Lo que procede destacar en este caso es, por contra, la trascendencia de este tipo de conflictos entre facciones antagónicas del cristianismo, puristas unas y más sincretistas otras, pues fue el triunfo de estas últimas, apoyado por el papado, lo que permitió al cristianismo difundirse entre un amplio espectro de la población (que se convirtió sin renunciar a muchas de sus anteriores prácticas religiosas), asumir el papel de religión protectora del Imperio y desplazar o integrar paulatinamente a la vieja religión romana. En el caso hispano, pocas dudas caben de que Basílides y Marcial recuperaron sus cátedras episcopales gracias al apoyo de gran parte de sus respectivas comunidades, de otros obispos del entorno y muy en particular del papa Esteban. El propio Cipriano reconoce el papel decisivo del obispo de Roma en la resolución de este tipo de conflictos, cuando en la carta que le dirigió hacia el 254 (Ep. 58), le rogaba que hiciese valer su autoridad para forzar la deposición del obispo Marciano de Arlés, que también había apostatado y se había adherido a la herejía de Novaciano. Es obvio que Cipriano le pedía a Esteban lo que él mismo no podía hacer, esto es, influir decisivamente sobre la permanencia o dimisión de un obispo. Algo similar debió de ocurrir en la Península con las dos comunidades de León-Astorga y Mérida $^{25}$. Lo que estaba en juego, conviene subrayarlo una vez más, no era simplemente una cuestión de autoridad, sino una concepción del cristianismo absolutamente incompatible con el ideario purista y sectario de los primeros siglos. De ahí la trascendencia de que un obispo apóstata como Basílides se sintiera legitimado para ejercer el episcopado y que sus aspiraciones se vieran avaladas por numerosos fieles y obispos. La clericatura, en suma, había dejado de ser un cargo carismático, reservado a fieles virtuosos, para convertirse en un puesto de relevancia social al que aspiran personajes cada vez más poderosos, como solía acaecer con las más importantes magistraturas del Imperio.

¿Indica esto que la iglesia hispana estaba contagiada de ceremoniales profanos y sumida en la mundanidad y el fanatismo, como aseguraba Harnack ${ }^{26}$ ? Plantearse este tipo de cuestiones o responder a ellas en cualquier sentido, como todavía se hace, supone adentrarse en un terreno equívoco y estéril, pues

${ }^{25}$ Algunos historiadores creen, sin embargo, que la opinión de Cipriano prevaleció (así, entre otros, E. SÁNCHEZ SALOR, «Los orígenes del Cristianismo en Hispania...» art. cit. p. 177), pero no hay argumento ni razonamiento convincente para mantener esta hipótesis. Cfr. sobre esta cuestión J. FERNÁNDEZ UBIÑA, «Doctrine, rituel et hiérarchie dans les premières communautés chrétiennes d'Hispania», en Dialogues d'Histoire Ancienne 17,1 (1991) 401-422; Idem, «Comunidades cristianas y jerarquía eclesiástica en la Hispania preconstantiniana», en J. Alvar (ed.) Homenaje al Profesor J. M. Blázquez. Antigüedad: religiones y sociedades, Madrid 1998, vol. VI, pp. 55-77.

${ }^{26}$ Para este eximio historiador alemán, la carta 67 y los cánones de Elvira dejan ya ver «el contraste, característico de la historia de la Iglesia española de todos los tiempos, entre una mundanidad vulgar y un rigorismo fanático» (op. cit. 540). 
implica tener una imagen idealizada de lo que es o debería ser el cristianismo y juzgar la realidad hispana del siglo III a partir de este prejuicio ideológico. Digamos, sencillamente, que nunca existió una comunidad cristiana ideal ni un cristianismo ideal, salvo como referente utópico o imaginario religioso de algunos creyentes. La realidad fue siempre, incluso en tiempos de Jesús, bastante más variada y prosaica. De otro modo no se explicaría que el cristianismo fuese tan amplia e intensamente menospreciado en todo el Imperio romano y por todas las clases sociales durante sus primeros siglos de existencia ${ }^{27}$.

Consecuentemente, quizá lo más acertado sería apreciar la importancia de esta nueva situación, donde los cristianos y sus dirigentes conviven armónicamente con el resto de los ciudadanos en diversas ciudades hispanas, algo que, como es sabido, también se constata en otras regiones del Imperio ${ }^{28}$. Todo lo cual viene, en fin, a confirmar que ese odio anticristiano tuvo una motivación religiosa y social menos irracional de lo que a menudo suele admitirse, incluso entre historiadores laicos, y que la política imperial adolecía en este ámbito de imprecisiones e incoherencias sorprendentes y extrañas para el ciudadano y los Estados del mundo moderno ${ }^{29}$.

Los obispos y fieles que practicaban su religión sin rupturas con el entorno pagano debieron de ser, si no mayoría, un porcentaje muy elevado, tanto en Hispania como en otras provincias romanas. Es lo que se deduce de la carta 67 de Cipriano, que ve en estas actitudes un signo evidente del final de los tiempos, una época, afirma, en que la dignidad episcopal sólo es defendida con firmeza por una porción del episcopado (VIII, 1). Tal amenaza escatológica es, de

\footnotetext{
${ }^{27}$ Lúcidas siguen siendo en este aspecto, todavía hoy, las breves páginas de T. MoMmSEN, «Christianity in the Roman Empire», en The Expositor, 4. ser. vol. 8 (1893), 1-7, recogido en Gesammelte Schriften: historische Schriften, III, Berlín, 1910, 540-545. La idealización casi mítica de estas primeras comunidades en la historiografía moderna, en particular la de inspiración protestante, carece, por lo demás, de fundamento histórico. Basta leer las cartas de Pablo a los corintios o la de Santiago, y no pocos pasajes evangélicos y de Hechos, para constatar las rivalidades y miserias que a menudo contagiaban a esos pioneros del cristianismo.

${ }_{28}$ Tertuliano menciona clérigos que proseguían con sus negocios como fabricantes de ídolos o sacaban lucrativos beneficios con prácticas mágicas (De idol.7 y 9) y también Cipriano (De lapsis 6) lamenta que muchos obispos se dedicaban a negocios múltiples con olvido de su cátedra, se unían en matrimonio con infieles y llevaban una vida de placer y dejación. Pero posiblemente el caso más llamativo, y estudiado, sea el de Pablo de Samosata, obispo de Antioquía en la segunda mitad del siglo III, al que se acusaba de ejercicio prepotente del poder episcopal, enriquecimiento ilícito a costa de la Iglesia y vida disipada, todo ello con el beneplácito de sus numerosos adeptos. Aunque fue depuesto por un concilio y se nombró a otro en su lugar, también Pablo, como Basílides, se negó a aceptar esta decisión y sus enemigos hubieron de apelar al emperador Aureliano (Eusebio de Cesarea, HE, VII, 29-30).

${ }^{29}$ Así lo ha destacado en particular M. BEARD, «The Roman and the Foreign: The Cult of the Great Mother in Imperial Rome», en N. ThOmas y C. Humphrey (eds.), Shamanism, History and the State, Ann Arbor 1994, pp. 164-190.
}

Hispania Sacra, LIX

120, julio-diciembre 2007, 427-458, ISSN: 0018-215-X 
hecho, su principal argumento para que los fieles de León-Astorga y Mérida no se desanimen ante «el número de prevaricadores o traidores que se han levantado ahora en la Iglesia contra la Iglesia» (VIII, 3). Desgraciadamente, Cipriano no es más preciso en este aspecto, y sólo afirma que algunos obispos hispanos (aliqui de collegis nostris) estaban en comunión con Basílides y Marcial, algo que él, lógicamente, desaprueba y desaconseja a los fieles de Hispania (IX, 1) ${ }^{30}$.

Desde 1967, año en que el profesor Díaz y Díaz escribió un trabajo innovador sobre los orígenes del cristianismo en España ${ }^{31}$, la carta 67 de Cipriano se ha considerado una prueba relevante de su procedencia africana. Entre los argumentos de Díaz y Díaz destacan estos dos: 1) que las comunidades cristianas solían apelar en aquellas fechas a sus iglesias madres y 2) que poco antes de la apelación de las dos comunidades hispanas a Cartago había sido transferida desde el norte de África hasta Astorga y León la recién fundada legio VII Gemi$n a$, y con ella pudieron llegar al norte peninsular los primeros cristianos. Aunque Díaz y Díaz daba otros argumentos y admitía la posibilidad de que algunos cristianos de Hispania se hubieran convertido en Roma, su hipótesis es insostenible y algo sorprendente, aunque sólo sea porque ni siquiera sabemos, en palabras del añorado Saxer, «d'où, ni par où, ni quand, ni comment le message chrétien parvint en Afrique» ${ }^{32}$. En ambas regiones -Hispania y África-, como en Roma, Italia y otras provincias occidentales, los orígenes del cristianismo, a más de ser múltiples, no marcaron de manera decisiva su evolución posterior, por lo que, según creo, en absoluto conviene dedicar mayor atención a este problema. Lo importante, como acabamos de ver, es que en esta parte occidental del Imperio, y particularmente en Hispania, no tenemos conocimiento de ningún grupo cristiano donde imperara el rigor doctrinal o la intransigencia disciplinaria propalada por teólogos como Tertuliano o Cipriano. Es muy probable que en las comunidades de León-Astorga y Mérida hubiera fieles y clérigos

\footnotetext{
${ }^{30}$ Conocemos muchos casos de clérigos apóstatas durante las persecuciones del siglo III e inicios del IV, sin que ello redundara siempre en su descrédito personal o religioso. El obispo de Lycopolis, por ejemplo, sacrificó el año 304 y, lejos de vivir avergonzado, siguió gozando de la simpatía popular. Lo mismo ocurrió con el obispo Plutarco de Sbeth, en Egipto (The Martyrology of Saint Coluthus, en E. A. E. Reymond y J. W. B. BARns, Four Martyrdoms from the Pierpont Morgan Coptic Codices, 1973, p. 147). Cfr. otros testimonios en Cipriano, 54, 10; Acta Pionii, 15, 2; Eusebio, HE, 8, 2 1s. Optato, 2, 25 , y el clarificador estudio de R. MACMULlEN, «Ordinary Christians in the Later Persecutions», en IDEM, Changes in the Roman Empire. Essays in the Ordinary, Princeton 1990, pp. 156-161.

${ }^{31}$ M. C. DíAZ y DíAZ, «En torno a los orígenes del Cristianismo hispánico», en Las raíces de España, Madrid, 1967, pp. 423-443 (reproducido, sin notas, en L. A. GARCíA Moreno (dir.), Historia de Andalucía II. Andalucía en la Antigüedad Tardía: de Diocleciano a don Rodrigo, Sevilla 2006, pp. 132 ss.).

32 V. SAXER, «L'Afrique chrétienne (180-260)», en J.-M. MAYEur, Ch. y L. PIETRI, A. VAucheZ, M. Venard, Histoire du Christianisme 1.- Le Nouveau Peuple (des origines à 250), Paris 2000, pp. 579-623, p. 583. Los primeros testimonios del cristianismo norteafricano -actas escilitanas y Tertuliano- son de finales del siglo II.
} 
próximos a este ideario norteafricano, que serían los adversarios de los obispos libeláticos de estas ciudades y los que buscaron el consejo y apoyo de Cipriano. Pero estos grupos no nos han dejado más testimonios históricos, fueron indudablemente los perdedores en el conflicto antes analizado y su influencia sería cada vez menor en éstas y otras ciudades hispanas ${ }^{33}$.

Aunque el espíritu carismático y purista de esta minoría perdedora no se extinguiría por completo en Hispania ni en Occidente, y lo veremos reverdecer en fechas más tardías, los cánones del concilio de Elvira, celebrado a principios del siglo IV ${ }^{34}$, confirman que la integración armoniosa de la jerarquía y del pueblo cristiano en la sociedad hispana ha seguido consolidándose en los decenios finales del siglo III. En Elvira no se documentan los casos extremos de apostasía episcopal denunciados en la carta 67 de Cipriano, pero la jerarquía clerical sigue teniendo comportamientos más propios de las magistraturas romanas que de los primeros misioneros cristianos, algo que, como hemos visto, no dejaba de escandalizar a Harnack.

Adelantemos, en primer lugar, que la visión desoladora del ilustre historiador alemán carece de fundamento, por cuanto hace extensible a toda la iglesia

${ }^{33}$ En España, las entonces novedosas y ponderadas hipótesis de Díaz y Díaz fueron de inmediato desarrolladas, aunque con algunas referencias inapropiadas, por J. M. BLÁZQUEZ («Posible origen africano del cristianismo español», en Archivo Español de Arqueología, 40 (1967), 30-50; Idem, «La carta 67 de Cipriano y el origen africano del cristianismo hispano», en Homenaje a Pedro Sáinz Rodríguez, III. Estudios históricos, Madrid 1986, reproducido en Idem, Religiones en la España antigua, Madrid 1991, 361-372). Mediante un análisis riguroso de las fuentes realmente pertinentes, M. SOTOMAYOR pondría finalmente las cosas en su sitio, haciendo ver la diversidad de orígenes y ritmos evolutivos del cristianismo hispano ( «Reflexión histórico-arqueológica sobre el supuesto origen africano del cristianismo hispano», en II Reunió d'arqueologia paleocristiana hispànica, Barcelona 1982, pp. 11-29; Idem, «Influencia de la Iglesia de Cartago en las iglesias hispanas. a propósito de un artículo de J. M ${ }^{\text {a }}$ Blázquez», en Gerión, 7 (1989, 277-287. Ambos trabajos han sido reproducidos en M. SoTOMAYOR, Discípulos de la Historia. Estudios sobre cristianismo, Granada 2002, pp. 193-222 y 223-239 respectivamente). También HARNACK (op. cit. 539, n. 2) había ya observado que la historia de la Iglesia española y de la africana se desarrollaron de manera independiente, como probaría, entre otras cosas, que el movimiento donatista no pasara el estrecho de Gibraltar.

${ }^{34}$ Las originales e innovadoras ideas del malogrado M. MeIgne ( Concile ou collection d'Elvire?», Revue d'Histoire Ecclésiastique 70 (1975), 361-387) sobre la posibilidad de que las actas del concilio de Elvira fuesen una colección de cánones procedentes de éste y otros concilios, han sido posteriormente desarrolladas con no tanto acierto y mesura por diversos historiadores. Un detallado estado de la cuestión puede verse en D. RAMOS-Lissón, «El concilio de Elvira en la historiografía moderna», en M. SOTOMAYOR y J. FERnÁNDEZ Ubĩ̃A (coords.), El concilio de Elvira y su tiempo, Granada 2005, 65-88, у M. SоTOMAYOR, «Valoración de las actas», Ibidem, 89-114. Estos autores defienden la hipótesis unitaria de los cánones iliberritanos y su datación a inicios del siglo IV, aunque sin descartar episódicas interpolaciones y añadidos. La posterior réplica de J. VILELla y P.-E. BARREDA («¿Cánones del concilio de Elvira o cánones pseudoiliberritanos?», Augustinianum 46 (2006), 285-373), reafirmándose en la idea de que ninguno de los 81 cánones pertenece a un concilio iliberritano, es en exceso puntillosa y, a mi juicio, poco convincente en el análisis histórico de algunos cánones.

Hispania Sacra, LIX

120, julio-diciembre 2007, 427-458, ISSN: 0018-215-X 
española lo que en realidad son conductas reprobadas y sancionadas por el concilio iliberritano, que además enfatiza el carácter escandaloso de las mismas ${ }^{35}$. Precisamente para eso, para sancionar y atajar tales comportamientos, se convocó y se reunió este concilio. Afirmar, pues, como hace Harnack, que las conductas allí condenadas prueban la mundanidad de toda la iglesia, es tan improcedente como suponer que la iglesia de Hispania desconocía conductas o actos pecaminosos no mencionados en Elvira, lo que nos llevaría a afirmar, por ejemplo, que no existió ni un solo ladrón, homosexual, embustero o blasfemo cristiano en toda la península, pues a ninguno de ellos se alude en este sínodo. ¿O acaso deberíamos pensar que la iglesia «española» estaba ya tan insanablemente contagiada que daba por buenos a fieles de esta calaña? Obnubilado por sus prejuicios anti-españoles, Harnack casi responde positivamente a esta cuestión cuando, malinterpretando el canon 51, escribe que España fue el único lugar donde los cristianos ortodoxos llamaban «fieles» a los herejes... ${ }^{36}$

Lo que realmente importa, pero difícilmente podemos aprehender, es la cuantificación absoluta y relativa de tales comportamientos. Las actas de Elvira no dan, por supuesto, esta información, pero sí nos ilustran sobre actitudes clericales que vienen a confirmar su plena compenetración con el mundo gentil. Recordemos, por ejemplo, que los clérigos contraen matrimonio y lo conciben a la manera romana, es decir, más como un acuerdo social que sentimental y sin las connotaciones sacramentales que adquirirá en fechas posteriores. De ahí que también ellos, aun cuando debían guardar castidad con sus esposas (can. 33), se vieran obligados a repudiarlas, siguiendo lo preceptuado por el derecho romano, si éstas cometían adulterio ${ }^{37}$. El concilio permite, por otra parte, que los clérigos sigan con sus actividades comerciales dentro de la provincia y da por supuesto que la mayoría podían realizar tales actividades lucrativas fuera de la misma valiéndose de un liberto, un familiar o un trabajador a su servicio (can. 19). El afán de riquezas debió de incitar a algunos clérigos a conceder préstamos con intereses, práctica que en estas fechas condenan todas las iglesias al igual que hace el can. 20 de Elvira.

\footnotetext{
35 Limitándonos al clero, cabe recordar que el can. 18 condena con excomunión perpetua los casos de fornicación por el escándalo causado, y el can. 65, que ordena a los clérigos repudiar a sus esposas adúlteras o ser excomulgados de por vida, justifica este rigor «para que no parezca que las enseñanzas de iniquidades provienen de aquellos que deben ser ejemplo de buena conducta».

${ }^{36} \mathrm{El}$ canon 51 comienza con la frase «Ex omni haerese fidelis si uenerit...», que equivale a la española «Si viene un bautizado procedente de cualquier clase de herejía...», y no da, por tanto, pie a la afirmación de HARNACK (op. cit. 542). En este como en los demás cánones iliberritanos sigo la precisa y reciente traducción de M. Sotomayor y T. Berdugo Villena (en M. Sotomayor y J. Fernández UBIÑA (coords.), El concilio de Elvira, op. cit. pp. 34-52).

${ }^{37}$ Cfr. un análisis más detenido sobre esta temática en J. FERNÁNDEZ UBIÑA, «Mujer y matrimonio en el concilio de Elvira», en M. SOTOMAYOR y J. FERnÁNDEZ UbiÑa (coords.), El concilio de Elvira, op. cit. pp. 275-322, esp. 314 ss.
} 
Estos testimonios no prueban, a mi juicio, declive alguno de la iglesia hispana, pues, como ya se ha reiterado, ello supondría admitir que en Hispania (o fuera de ella) existió con anterioridad una iglesia estructurada y guiada por principios y conductas de intachable espiritualidad. No nos consta que fuera así $\mathrm{y}$, en consecuencia, lo que cabe deducir de estos cánones es el avanzado aggiornamento del cristianismo peninsular y su capacidad potencial para vertebrar la sociedad de su tiempo, como hasta ahora venía haciendo la religión romana, sin cambios traumáticos en las mentalidades o la vida social.

\subsection{El sincretismo religioso: creencias y prácticas cristianas}

Esta cristianización sin rupturas de la sociedad hispana o, si se prefiere, la profunda romanización del cristianismo, se deja ver con similar claridad en las creencias y comportamientos religiosos del pueblo, tanto por parte de los viejos gentiles como de los nuevos cristianos.

Desde la perspectiva gentil o pagana, lo más significativo es, sin duda, la conversión de flámines y sacerdotes paganos que, según atestigua el concilio de Elvira, no por ello renunciaron a su hábitos religiosos (cans. 2-4, 55) ${ }^{38}$, o la no menos superficial de catecúmenos que ni siquiera iban a la iglesia (can. 45). Para ninguno de ellos la conversión al cristianismo debió significar una decisión trascendental y un cambio radical en sus formas de vida, a la manera que solemos figurar en Pablo (respecto al judaísmo) o Agustín (respecto al paganismo). Que esta decisión la tomasen miembros de las oligarquías urbanas prueba, por contra, el prestigio de la iglesia en algunas ciudades hispanas y que el cursus honorum municipal y eclesiástico no eran para ellos incompatibles, como viene a ratificar el canon 56, que permite a los cristianos ejercer magistraturas ciudadanas, cuyas competencias, como se sabe, incluían actividades relacionadas con rituales y fiestas politeístas ${ }^{39}$. Esta predisposición favorable del entorno gentil hacia el cristianismo se pone igualmente de relieve en el canon 39, que permite el bautismo de enfermos paganos, es decir, de gente que, aun viviendo alejada del cristianismo, busca en él un viaticum mortis ${ }^{40}$.

\footnotetext{
${ }^{38} \mathrm{El}$ tema fue magistralmente estudiado por L. DuCHESNE en un breve trabajo que no ha perdido un ápice de actualidad («Le Concile d'Elvire et les flamines chrétiens», en Mélanges Renier, Paris 1887, pp. 159-174). Sobre el clero en general, véase ahora A. GonZÁlez BlANCO, «Clero y espiritualidad. Transformaciones y novedades en el concilio de Elvira», en M. SOTOMAYOR y J. FERNÁNDEZ UBIÑA (coords), El concilio de Elvira, op. cit. pp. 229-274, y las observaciones críticas de R. GonZÁLEZ SALINERO en Gerión 24, 2 (2006), 115-116.

39 Tertuliano (De idol. 17) decía irónicamente que un cristiano podía ser magistrado si no sacrificaba o tomaba parte en sacrificios, ni se preocupaba del cuidado de los templos, ni costeaba espectáculos públicos... Es decir, la incompatibilidad era absolutamente insuperable.

${ }^{40}$ HARNACK, op. cit. 541.
}

Hispania Sacra, LIX

120, julio-diciembre 2007, 427-458, ISSN: 0018-215-X 
Similar espíritu de convivencia se constata igualmente, desde el lado cristiano, en la activa participación de fieles, hombres y mujeres, en procesiones (can. 57) y cultos idolátricos (cans. 1 y 59), mientras otros cristianos apenas iban a la iglesia (can. 21) e incluso apostataban (can. 46). No es menos significativo que algunos possessores aceptasen como rentas los bienes ofrecidos a los ídolos (can. 40) o permitiesen la permanencia de imágenes idolátricas en sus casas porque temían que sus esclavos reaccionaran violentamente si las quitaban (can. 41). No es fácil entender lo que pretendía el canon 36 al prohibir pintar en las paredes de las iglesias lo que era digno de adoración, pero no parece muy desacertado pensar que de este modo se quería evitar el espíritu pagano con que muchos fieles veneraban esas pinturas ${ }^{41}$.

Los cánones de Elvira ratifican, como tan gráficamente mostró Hopkins, que aquel era, en efecto, un mundo lleno de dioses, de dioses de todo género y presentes en todas partes, temibles a veces y benefactores otras, pero a los que siempre se dirige el ciudadano sin el dramatismo espiritual o psicológico difundido inicialmente por las religiones monoteístas ${ }^{42}$. Los padres sinodales respiran esta atmósfera sobrecargada de seres sobrenaturales en los que creen y a los que temen al igual que lo hacían sus compatriotas gentiles. Recordemos, tan sólo como botón de muestra, su condena del homicidio mediante maleficios idolátricos (can. 6), su temor a perturbar los espíritus de los difuntos si se encienden cirios en los cementerios (can. 36) o sus prevenciones ante la participación de energúmenos - personas poseídas por espíritus inmundos- en rituales cristianos, como el bautismo o la eucaristía (can. 37).

Consecuencia lógica de este clima sincretista es la oposición conciliar al destrozo de imágenes idolátricas (can. 60), para evitar así enfrentamientos tan graves como los vividos poco antes en Hispalis, cuando las fieles Justa y Rufina destrozaron el ídolo que la gente llevaba en procesión con ocasión de las fiestas de las Adonías ${ }^{43}$. Y de igual modo cabe explicar la relativa indulgencia con los casos de apostasía (can. 46), la tolerancia inevitable de frecuentes matrimonios mixtos (can. 15) o la ya citada permisividad ante el ejercicio de magistraturas por cristianos (can. 56). Este ánimo de convivencia con el entorno gentil queda aún más realzado cuando se compara con la intolerancia cristiana

${ }^{41}$ Es la hipótesis de HaRnACK (o. c. 541). Sobre este canon, objeto de innumerables estudios, cfr. en último lugar M. PARISI, «Ne picturae in ecclesia fiant. Storia e interpretazioni del canone 36 del concilio di Elvira dalla seconda metà dell'Ottocento alla fine del Novecento», en Guttadauro 3 (2003), 145-172.

${ }^{42}$ K. Hopkins, A World Full of Gods, op. cit. 7 ss.

${ }^{43} \mathrm{El}$ mejor estudio sobre este trágico acontecimiento, acaecido probablemente el año 287, sigue siendo el de F. Cumont, «Les syriens en Espagne et les Adonies à Seville», en Syria 8 (1927), 330-41. Cfr. además M. Sotomayor, Historia de la Iglesia en España, op. cit. pp. 62-65. 
frente a herejes (cans. 16, 22 y 51) y judíos (cans. 16, 49, 50 y 78), sobre los cuales sólo se aprueban medidas de condena y segregación ${ }^{44}$.

Detrás de esta convivencia, y como requisito fundamental de la misma, subyacía la identificación social y política entre gentiles y cristianos, muy especialmente entre sus clases dirigentes. Así se observa en la cristianización de las élites urbanas de Hispania, de sus magistrados, sacerdotes, terratenientes y esclavistas (cans. 2-5, 20, 40, 41, 49, 55, 57), sectores a los que presta especial atención el concilio, mientras que al pueblo llano y a los sectores serviles sólo se alude para censurar su apego a las viejas tradiciones (cans. 40-41) o para recordar que tienen vetado el acceso a la clericatura (can. 80). En una sociedad tan fuertemente clasista como la romana, donde la hegemonía social e ideológica recaía en una reducida minoría de potentados locales, la influencia real del cristianismo pudo ser muy superior a lo que su presencia numérica puede hacernos creer, gracias a esta cristianización de las élites ciudadanas. A tenor de la documentación disponible, fue con toda probabilidad a través de estas minorías privilegiadas como el cristianismo se implantó en Hispania, como en otras regiones de Occidente, lo que vendría igualmente a explicar su espíritu integrador, alejado del sectarismo judío o filosófico de los primeros siglos, y su voluntad y capacidad de constituirse en una religión vertebradora de todo el cuerpo social.

El papel secundario asignado a la mujer es, en este sentido, significativo. $\mathrm{Si}$ la carta 67 de Cipriano ni siquiera la menciona, lo cual podría ser algo casual y nada nos permite conjeturar al respecto, en el concilio de Elvira se alude a ellas con frecuencia y siempre para subrayar su situación marginal dentro de la comunidad. No se podía esperar otra cosa de una sociedad patriarcal como la del Bajo Imperio en la que, además, se vivía un proceso de reforzamiento de las actitudes y valores misóginos tras los decenios de libertad relativa que había disfrutado la mujer entre el final de la República y el reinado de los Antoninos ${ }^{45}$. Sin entrar en detalles y destacando sólo los aspectos más importantes de la dependencia femenina, cabría citar su escaso protagonismo en los acuerdos nupciales, que son competencia exclusiva del paterfamilias y de ahí que a él responsabilice el concilio si son vulnerados (can. 54), el rigor especial aplicado al adulterio femenino y, en fin, la desconfianza general con que se contempla la

${ }^{44}$ Cfr. el excelente análisis y estado de la cuestión realizado recientemente por R. TEJA, «Exterae gentes: relaciones con paganos, judíos y herejes en los cánones de Elvira», en M. SOTOMAYOR y J. FeRNÁNDEZ UBIÑA (coords.), El concilio de Elvira, op. cit. pp. 197-228.

${ }^{45}$ Sobre pocos aspectos de la sociedad romana se ha escrito tanto como sobre la situación de la mujer. Entre los estudios que afectan al tema aquí tratado merecen destacarse los magistrales de P. VeYNE, «La familia y el amor en el Alto Imperio romano», en Idem, La sociedad romana, Madrid, 1990, pp. 169-211 y L. Cracco RugginI, «Judicial Status and Historical Role of Women in Roman Patriarcal Society», en Klio, 71 (1989), 604-619.

Hispania Sacra, LIX

120, julio-diciembre 2007, 427-458, ISSN: 0018-215-X 
vida pública, religiosa o no, de las mujeres ${ }^{46}$. Muy de acuerdo con la mentalidad dominante, los padres conciliares nunca conciben a la mujer como persona potencialmente independiente, soltera o divorciada, sino siempre bajo la tutela de un hombre, su marido o su padre. Es cierto que el cristianismo abrió un nuevo espacio social para ellas, el de la propia Iglesia, donde muchas encontraron, en calidad de vírgenes o viudas, una vida probablemente más libre y satisfactoria que la previsible en el matrimonio o concubinato tradicional romano. En el concilio de Elvira apenas se alude a estas mujeres (cans. 13-14), pero sabemos por otras fuentes que fueron sobre todo las de alta posición social quienes siguieron este camino, a pesar de tener vedado el acceso a la jerarquía y a los ministerios, y que muchas de ellas dieron un renovado impulso a la misión cristiana entre mujeres de todos los sectores sociales. En Elvira se habla mucho más de la mujer en relación con el matrimonio, sacralizando su fidelidad al pacto conyugal, su dependencia del esposo y su misión reproductora. De este modo, la Iglesia hispana encontró en la mujer una doble vía para su difusión y arraigo: mediante el ejemplo y el apoyo de las capas altas (a las que debían pertenecer muchas vírgenes y viudas) y mediante las esposas y madres que difundían la nueva fe en su entorno familiar, especialmente entre sus hijos, que probablemente eran por término medio más numerosos que en las familias tradicionales romanas ${ }^{47}$. En ambos casos, la hegemonía espiritual recaía en las capas superiores y debió fortalecer, en consecuencia, el carácter sincretista e integrador del cristianismo hispano.

\section{El Concilio de Elvira y los oríGenes del Cristianismo en HisPania}

El trabajo pionero antes citado de Díaz y Díaz defendiendo un origen predominantemente africano del cristianismo hispano, también basa su hipótesis en las actas de Elvira, especialmente en el elevado número de sedes representadas por un presbítero, sobre todo en la Bética, que presumiblemente fue la provincia primera y más densamente cristianizada de toda Hispania. Dado que las comunidades presididas por un presbítero estaban muy extendidas en algunas zo-

\footnotetext{
${ }^{46}$ Se le prohíbe, entre otras cosas, cartearse con laicos (can. 81) o velar en los cementerios «porque a menudo, bajo pretexto de oración, cometen ocultamente acciones inicuas» (can. 35). Para un análisis pormenorizado de éstos y otros cánones sobre la mujer, cfr. J. FERNÁNDEZ UBIÑA, «Mujer y matrimonio en el concilio de Elvira», op. cit. pp. 283 ss.

${ }^{47}$ Aunque no podemos precisar en qué medida la prohibición del divorcio (cans. 8 y 9), del aborto (cans. 63 y 68) y de la exposición de recién nacidos pudo incidir en el mayor número de hijos en familias cristianas, es obvio que tales principios, que rompían una tradición secular de permisividad legal en este ámbito, sólo pudieron afectar positivamente al aumento de la prole. Cfr. sobre este punto las interesantes observaciones sociológicas de R. STARK, The Rise of Christianity. A Sociologist Reconsiders History, Princeton 1996, cap. 5 («The Role of Women in Christian Growth»).
} 
nas de África y eran poco frecuentes en el resto de Occidente, esta coincidencia vendría a avalar los orígenes africanos del cristianismo bético. Para Díaz y Díaz es, en cambio, irrelevante, que el montanismo y el donatismo, tan vigorosamente presentes en África, no se documenten en la Península, por ser fenómenos típicos de alguna región norteafricana ${ }^{48}$.

El tema ha sido recientemente estudiado por el profesor García Moreno desde una perspectiva diferente, pues advierte que «nada sería tan perverso metodológicamente que considerar uno solo el origen del Cristianismo peninsular», y apunta, en cambio, que la diversidad de origen debió quedar reflejada en la estructura territorial de las comunidades hispanas ${ }^{49}$. Esta estructura territorial no es otra que la reflejada en el mapa de las iglesias representadas en Elvira, cuyos rasgos más llamativos serían: 1) acumulación de comunidades en la Bética y el Sureste peninsular, y dispersión en el resto (que constituye más de tres cuartos del total), donde sólo se atestiguan 6 iglesias (Faro, Mérida, Zaragoza, León, Toledo y Talavera). 2) Especial concentración (21 comunidades) entre las serranías béticas y la periferia del valle del Guadalquivir. 3) Sorprendente y significativa coincidencia de este mapa de comunidades cristianas con el de aljamas judías de la Antigüedad ${ }^{50}$. 4) Esta distribución geográfica hace pensar en dos grandes vías de comunicación por las que llegó el cristianismo: una, las que procedentes de las ciudades costeras de Cartagena y Urci confluían en Acci (Guadix), y otra la que unía Málaga con Écija y Córdoba (con bifurcación en Singilia Barba).

Estas vías de penetración hacen pensar a García Moreno en un origen norteafricano de los primeros misioneros, pues los viajeros procedentes de Roma normalmente arribaban al puerto de Tarragona. Esta procedencia quedaría, según él, indirectamente reflejada en la passio de Ciriaco y Paula, mártires de posible origen mauritano cuyo culto llegó a Urci. A estos indicios habría que añadir la particularidad, ya señalada, de iglesias regidas por presbíteros, si bien advierte que éstos estaban al frente de una diócesis subordinada a una sede episcopal. Estas iglesias diocesanas solían convertirse en episcopados, como ocurrió en África, pero esta evolución no se dio en Hispania probablemente por la oposición decisiva de Osio de Córdoba, deseoso de que el poder episcopal no se depreciara con semejante inflación de sedes. De este modo, lo único en co-

48 Op. cit. 441. A estos argumentos, J. M. BLÁzQUEZ («La carta 67 de Cipriano...» o. c. pp. 371372) añadió una larga relación de aparentes similitudes doctrinales sobre la mujer y la sexualidad apreciables en las actas iliberritanas, Tertuliano y Cipriano. Pero todos ellos son tan irrelevante para probar un origen africano del cristianismo peninsular que el propio autor, sorprendentemente, así lo reconoce en la conclusión de su estudio.

${ }^{49}$ L. A. GarCÍA MoReno, «El Cristianismo en las Españas...» op. cit. p. 177.

${ }^{50} \mathrm{Cfr}$. el mapa elaborado por el propio García Moreno en su obra Los judíos de la España antigua, Madrid 1993, p. 61.

Hispania Sacra, LIX

120, julio-diciembre 2007, 427-458, ISSN: 0018-215-X 
mún que al cabo perviviría entre la cristiandad hispana y la africana sería el uso del término dioecesis para referirse a este tipo de iglesias, mientras que en Italia y las Galias solía emplearse el de parrocia.

Un argumento final sobre el origen africano de las iglesias meridionales hispanas sería, según García Moreno, el canon 58 de Elvira, que alude a «la primera cátedra del episcopado». Tanto en África como en Iliberis, la expresión prima cathedra designa la sede ocupada por el obispo de ordenación más antigua. De este modo no sólo se confirmaría el origen, sino también la organización similar de las comunidades cristianas de ambas regiones.

Sin embargo, como señala este mismo historiador, responder a la pregunta «de dónde» no presupone la de «cuándo», cuya importancia no es ciertamente menor. A esta segunda cuestión no se atreve a dar una respuesta precisa, pero apunta algo de singular interés: aunque podría imaginarse, a priori, que las iglesias «africanistas» del sur se constituyeron hacia mediados del siglo II, la lista episcopal de Iliberis transmitida por el códice Emilianense no permite situar su primer obispo antes de mediados del siglo siguiente, es decir, en torno al 250, seguramente porque no se tenían recuerdos previos sobre fastos episcopales, al igual que debió de ocurrir en Toledo y Sevilla, cuyas listas episcopales -transmitidas también por el Emilianense- tampoco permiten retroceder más en el tiempo.

No creo que, con la documentación hoy disponible, se pueda decir más y por supuesto nada más razonable que lo anteriormente expuesto acerca de los problemas relativos a «cuándo» $\mathrm{y}$ «de dónde». Y lo que estas respuestas nos dicen viene a confirmar las tesis antes desarrolladas sobre los difusores y seguidores del primer cristianismo hispano. Pero si admitimos que esta primera evangelización no se produjo con anterioridad al siglo III, su coincidencia geográfica con el mapa de aljamas judías plantea un nuevo problema, dado que, desde mucho antes de esta época, el cristianismo era una religión enfrentada irreconciliablemente con el judaísmo. ¿Cómo vino, pues, a implantarse en las mismas ciudades donde dominaba la religión judía, es decir, sus principales enemigos? Sabemos, en efecto, que tras los grandes desastres sufridos en el siglo I y II, en especial la represión brutal de las revueltas de los años 66-73, 117 y 132-135, el judaísmo reforzó sus señas espirituales de identidad y su carácter nacional. De este modo, se era judío porque se nacía judío, siendo en consecuencia muy pocos los excluidos o los conversos incorporados del exterior ${ }^{51}$. $\mathrm{Y}$ al mismo tiem-

\footnotetext{
51 Así lo ha probado convincentemente M. Goodman, Mission and Conversion, Oxford, 1994. Por otra parte, como recuerda G. W. Clarke («The Origins and Spread of Christianity», Cambridge Ancient History, X ( 2001), pp. 848-872, esp. p. 864), durante los primeros siglos de nuestra era los asentamientos judíos del Mediterráneo occidental fueron escasos y además las simpatías hacia este pueblo iban a menos conforme avanzamos hacia Occidente.
} 
po, el cristianismo aumentó su conciencia de religión autónoma, en gran medida acentuando sus rasgos diferenciales y su oposición hacia sus antepasados judíos. La consecuencia fue que ambos debieron de mantener una difícil coexistencia. Es bien sabido que el cristianismo también tuvo difíciles relaciones con la religión romana en general y con algunas religiones mistéricas en particular, pero su enfrentamiento con el judaísmo, al ser de naturaleza puramente teológica, dio como resultado una situación sumamente peculiar, pues si bien sus dirigentes caldeaban el odio religioso tachando a los judíos de deicidas y obtusos ignorantes de las profecías bíblicas, los fieles de una y otra religión solían convivir armoniosamente por compartir todos ellos formas de vida similares. La convivencia espontánea del pueblo era así constantemente demonizada desde las sinagogas y las iglesias, como si la voluntad de dios fuera precisamente el alejamiento y el desprecio mutuos.

$\mathrm{Si}$, en suma, el cristianismo que arraigó en Hispania a inicios del siglo III llevaba el sello del antijudaísmo, su presencia y desarrollo no pueden explicarse ni por la misión en aljamas judías, ni por la conversión significativa de judíos. Y la coexistencia de ambas religiones en tantas ciudades del sur y levante hispano tampoco puede atribuirse a la influencia de misioneros cristianos llegados de África, donde el antijudaísmo fue propagado por sus dirigentes desde épocas muy antiguas, como atestigua la obra de Tertuliano. La razón de esta coexistencia sólo pudo ser sociológica, no religiosa, es decir, el simple hecho de que la mayoría de sus fieles, como la de tantas otras religiones mistéricas, procedían de los mismos estratos sociales y compartían idearios espirituales similares.

El concilio de Elvira nos da preciosas informaciones al respecto, pues confirma, en efecto, esta convivencia cotidiana en las mismas ciudades y, además, un fuerte atractivo del judaísmo sobre los fieles y dirigentes cristianos, sin que se constate, en cambio, el proceso inverso, esto es, el atractivo espiritual del cristianismo sobre el pueblo judío ${ }^{52}$. Que se prohíban los matrimonios de cristianas con judíos (can. 16) prueba, a más de su existencia, el similar rango social de unos y otros, pues sabemos que el matrimonio en esta época es esencialmente un acuerdo entre familias de parecido rango y posición económica, y quizá deberíamos deducir lo mismo del can. 78, que condena el adulterio con mujeres judías. De hecho el canon 49, que prohíbe a los cristianos dejar bendecir los frutos de sus campos por judíos, prueba esta acomodada posición social y económica de muchos cristianos. Que algunos clérigos, en fin, gustaran com-

\footnotetext{
52 Cfr. L. García Iglesias, Los judíos en la España Antigua, Madrid, 1978, p. 70 y F. J. Lomas, «Comunidades judeocristianas granadinas. Consideraciones sobre la homilética de Gregorio de Elvira», en C. GonZÁlez (ed.), La sociedad de la Bética. Contribuciones para su estudio, Granada 1994, pp. 319-44.
}

Hispania Sacra, LIX

120, julio-diciembre 2007, 427-458, ISSN: 0018-215-X 
partir la mesa con judíos, según condena el canon 50, desvela igualmente la situación acomodada de éstos y la tendencia de todos a compartir experiencias de orden social y espiritual.

Lo importante, en resumen, no es sólo de dónde y cuándo llegó el cristianismo, sino ante todo quién lo trajo y entre quién se difundió. Los cánones de Elvira comentados en el epígrafe anterior y los cuatro referentes a la relación con los judíos vienen a ratificar que la nueva fe era a inicios del siglo IV, y seguramente lo fue desde sus orígenes algunos decenios atrás, una religión difundida y compartida por sectores acomodados de las ciudades, ciudadanos romanos que ocupaban a veces sus magistraturas y formaban parte de las oligarquías terratenientes urbanas, gente, en fin, que asumió el cristianismo como parte de su cultura espiritual clásica, sin espíritu de oposición y ruptura con el Imperio y sus instituciones, del mismo modo que lo hacían las influyentes minorías judías de Hispania. En ese espíritu integrador y sincretista debieron de sumarse una multitud no cuantificable de personal dependiente, esclavos, libertos o arrendatarios, a los cuales todavía contempla el concilio de Elvira como un sector marginal cuya cristianización preocupa muchísimo menos, acaso nada, que la de los sectores hegemónicos ya convertidos, cuya vida y conducta es la única que intentan regular los Padres sinodales en consonancia con los principios propios, y a menudo imprecisos, de su fe.

\section{El testimonio de OSIO}

Osio es el primer cristiano hispano del que conocemos con cierto detalle su ideario y vida religiosa, en gran medida gracias a su propio testimonio. Y, además, su condición de obispo, consejero imperial y activista niceno nos da una información singular sobre todas las cuestiones que estamos tratando ${ }^{53}$. Adelantemos, por otra parte, que nada de lo que sabemos de este insigne y longevo obispo desentona con las numerosas medidas tomadas en el concilio de Elvira, en el que participó. Por el contrario, es probable que él mismo llevase algunos acuerdos iliberritanos al orden del día de otros concilios, aunque no siempre lograra su ratificación. Interesa este dato porque prueba que Osio se mantuvo fiel

\footnotetext{
${ }^{53}$ No entramos en los pormenores de su actividad pública, al servicio del Imperio y de la Iglesia, que hemos analizado en dos artículos recientes: J. FERNÁNDEZ UBIÑA, «Osio de Córdoba, el Imperio y la Iglesia del siglo IV», en Gerión 18 (2000), 439-473. Idem, «El obispo y la ciudad. Aspectos seculares del poder episcopal en Osio de Córdoba», en C. GonZÁleZ y A. PADILla (eds.), Estudios sobre las ciudades de la Bética, Granada 2002, pp. 149-175. El mejor estudio monográfico sigue siendo, en lo que conozco, el de V. C. de ClercQ, Ossius of Cordova. A Contribution to the History of the Constantinian Period, Washington 1954.
} 
a las mismas ideas religiosas toda su vida ${ }^{54}$, de modo que su testimonio es también el de un sector muy amplio del primer cristianismo hispano.

Al igual que él y otra treintena de clérigos hicieron en Elvira a inicios del siglo IV, en los decenios siguientes, hasta su muerte ya centenario hacia el año 358, Osio se preocupó ante todo por fijar y hacer cumplir la disciplina eclesiástica, por institucionalizar y realzar la autoridad episcopal y por consolidar las buenas relaciones de la Iglesia con el Estado romano. Así se observa en los cánones aprobados a instancia suya en el concilio de Sérdica (342 o 343), que él mismo presidió. En este caso lo más destacado fue, en esencia, la redacción de una especie de constitutio de episcopis, que delimitaba al ámbito ciudadano la jurisdicción episcopal (can. 14), vetaba las ambiciones clericales de ocupar fraudulentamente las principales sedes (cans. 1-2), atajaba la búsqueda de prebendas en la Corte (cans. 8 y 9) y trataba, en fin, de impedir que personajes poderosos procedentes de la administración civil o del laicado se valieran de las cátedras episcopales para su beneficio personal (can. 13). Aparte de esto, ningún acuerdo de Sérdica interesó a la espiritualidad cristiana en sentido estricto, aunque sí se censuraba la escasa atención a su grey de algunos clérigos (can. 15)

La implicación de Osio en los conflictos donatista y arriano estuvo más orientada a restablecer la paz entre diversas corrientes cristianas, buscando casi siempre la solución que más convenía a los emperadores y a la Iglesia nicena. Desgraciadamente, sabemos muy poco de su implicación en el cisma donatista norteafricano, salvo que los cismáticos censuraron su actuación y guardaron un recuerdo deplorable de su comportamiento, culpándolo en particular de la dura represión constantiniana de los años 316 y 317. Parmeniano, sucesor de Donato en la sede episcopal de Cartago, aseguraba que su responsabilidad fue incluso superior a la de Constantino (ya que éste habría actuado engañado por sus perversos consejeros), y lo culpaba además de haber influido sobre numerosos obispos hispanos, galos e italianos para que negaran la comunión a los donatistas. Por tan insidioso comportamiento, afirmaban, Osio fue juzgado y condenado en Hispania, siendo posteriormente absuelto por obispos galos ${ }^{56}$.

\footnotetext{
${ }^{54}$ Creo haber probado que incluso su acuerdo con el Credo homeo de Sirmio (357) no supuso una traición a su ideario, sino un intento frustrado y desafortunado de reconciliación entre las principales tendencias religiosas del cristianismo en la segunda mitad del siglo IV. Cfr. en particular J. FERNÁNDEZ UBIÑA, «Los Arrianos hispanorromanos del siglo IV», en Studia Ephemeridis Augustinianum 46 (1994), 385-391.

${ }^{55}$ La edición latina y griega de los cánones de Sérdica, con versión al inglés y un estudio pormenorizado de cada uno, puede verse en H. HESS, The Early Development of Canon Law and the Council of Serdica, Oxford 2002. En las referencias a sus cánones seguimos la numeración del texto latino, que no siempre concuerda con la del griego.

${ }^{56}$ Agustín, C. Parm. 1.8.13. Sobre la actividad antidonatista de Osio en las provincias y ante el emperador, cfr. Ag. Ibid. 1.2.2; 1.4.6; 1.5.10; 1.6.11; 1.8.13; C. Cresc. 3.61.67. Agustín exculpará poste-

Hispania Sacra, LIX

120, julio-diciembre 2007, 427-458, ISSN: 0018-215-X
} 
Mucho más rica y fiable es nuestra documentación sobre el papel desempeñado por Osio en el conflicto arriano, aunque aquí sólo destacaremos de manera sucinta lo que mejor perfila sus líneas de actuación. En un primer momento, hacia el 324, Osio intervino como consejero y embajador de Constantino procurando reconciliar a las partes en conflicto, sobre todo a Arrio con su obispo Alejandro de Alejandría ${ }^{57}$. No lo consiguió, como tampoco lo hizo el concilio de Nicea (325), donde Osio tuvo un protagonismo relevante en la imposición del Credo niceno, y la querella no haría sino extenderse y complicarse en los años siguientes ${ }^{58}$. Con toda probabilidad esto debió provocar su apartamiento de la Corte, donde el propio emperador adoptaba posiciones más conciliatorias y próximas a los arrianos. Osio, en cambio, acentuó en aquellos años su radicalismo niceno y antiarriano, como lo muestra su entrañable amistad con Atanasio de Alejandría y, sobre todo, su actuación en el concilio de Sérdica, antes mencionado, que fue en esencia un ajuste de cuentas, amparado por el emperador ortodoxo Constante, contra las figuras más señeras del arrianismo oriental. Es muy probable que el obispo cordobés destacara en esta actitud vengativa, pues de otro modo parecería en exceso desproporcionado que el grupo de obispos orientales que abandonó aquel sínodo lo tachara de criminal, difamador, amigo de delincuentes y de obispos excomulgados (en alusión a Atanasio), conspirador eclesiástico y enemigo de Dios ${ }^{59}$. Lo cierto es que la figura de Osio ganó desde entonces, y hasta su muerte, una fama imborrable de intransigencia y crueldad, que se puso especialmente de manifiesto en el Libellus precum, un escrito de súplicas dirigido el año 384 al emperador Teodosio por los presbíteros romanos Marcelino y Faustino. A Osio se le describe como un obispo timorato que en el concilio de Sirmio (357) renegó de la ortodoxia nicena por temor a perder su posición social y colaboró seguidamente en la imposición de la herejía arriana recurriendo a toda clase de medios, incluyendo la coacción ${ }^{60}$.

riormente a Osio asegurando que su condena en Hispania se debió a una serie de acusaciones calumniosas y de ahí la posterior absolución por sus colegas galos (C. Parm. 1.4.7).

${ }^{57}$ Eusebio de Cesarea, Vita Constantini 2. 64-72; Sócrates, HE 1.7.

${ }^{58}$ En esta época, en la que tuvieron lugar acontecimientos tan cruciales, la influencia de Osio derivaba más de su amistad con Constantino que de su perspicacia teológica o de su escaso talante diplomático, todo lo cual ayudará poco a la resolución satisfactoria de estos conflictos. Cfr. M. SimONETTI, «La crisi ariana e l'inizio della riflessione teologica in Spagna», en Hispania romana, Roma 1974, pp. 127-47, esp. p. 128.

${ }^{59}$ Dec. Syn Or. a parte arian. 27 (CSEL 65, p. 66).

${ }^{60}$ Para un análisis detallado de este documento, cfr. J. FERNÁNDEZ UBIÑa, «El Libellus precum y los conflictos religiosos en la Hispania de Teodosio», en Florentia Iliberritana 8 (1997), 103-123. La edición latina de esta obra, con un amplio estudio y traducción francesa a cargo de Aline Canellis, puede ahora verse en FAUSTIN et MARCELLIN, Supplique aux empereurs (libellus precum et lex avgvsta), Paris 2006 (Sources chrétiennes, $\mathrm{n}^{\circ}$ 504). 
Con estos datos y el antiespañolismo de siglos pasados no extraña que Duchesne viera en Osio «un español de pura cepa, autoritario, duro e inflexible» 61 . Seguramente fue todo ello, salvo español, pues faltaba todavía mucho para que existiera España. Osio fue un cristiano a la manera que solían serlo los romanos de su tiempo comprometidos no sólo con su fe sino también con el bienestar y la seguridad del Estado. Y probablemente no fue menos virtuoso que los obispos galos (no sé si Duchesne diría franceses o alemanes) que condenaron a Prisciliano en Tréveris el año 385 instigados por el usurpador Máximo. Pero hemos de insistir, una vez más, en que este tipo de interpretaciones, teñidas de sentimientos ideológicos modernos, son equívocas y olvidan lo fundamental, esto es, que el cristianismo juega en ese tiempo un papel polivalente, como toda religión sincretista y comprometida con los poderes públicos. Osio y la Iglesia que él conoció debían ante todo probar la bondad del cristianismo como religión integradora y protectora del Imperio, y de ahí sus compromisos políticos, sociales y hasta militares. En esto, para decirlo crudamente, en nada difería de la religión tradicional romana ni diferirá, por ejemplo, del Islam.

Pero eso no implica que el cristianismo y los obispos de este tiempo, y menos la comunidad cristiana en general, hubieran olvidado los valores espirituales o humanitarios de su fe, algo que, como es sabido, interesa poco en la gestión política o militar. Esos valores apenas se vislumbran en las fuentes antes mencionadas, que tienen un carácter preferentemente disciplinario o normativo, pero sí se ponen de relieve en otros textos de la época que mencionaremos enseguida. El propio Osio dio testimonio de ellos, por ejemplo, en su resistencia como confesor ante la persecución de Maximiano ${ }^{62}$, en su defensa de la castidad sacerdotal y la virginidad, en su denuncia de la corrupción episcopal y, por supuesto, en su profunda fe cristiana, sin la cual sería difícil entender que, ya octogenario, tuviera fuerzas para recorrer el Imperio de parte a parte, en las duras condiciones de su tiempo, asistiendo o presidiendo concilios en ciudades situadas a miles de $\mathrm{km}$ de su Córdoba natal, para defender y propalar sus ideas religiosas.

\section{EPÍlOGO. LA ESPIRITUALIDAD TRUNCADA}

La tardía implantación del cristianismo en Hispania y su consiguiente naturaleza sincretista, explica que la fe o las esperanzas escatológicas de los prime-

${ }^{61}$ L. DuCheSNE, Los seis primeros siglos de la Iglesia (Historia crítica), Barcelona 1911, vol. II, 191.

${ }^{62}$ Atanasio de Alejandría lo llama confesor en un par de ocasiones (Hist. arian. 28 y 42) y el propio Osio se presenta como tal en la carta que escribió a Constancio, que también nos ha llegado en la copia preservada por Atanasio (Ibid. 44; cfr. Soz. HE 1.10). La versión castellana de esta carta puede verse en Z. García VILlada, Historia eclesiástica de España I, 2, Madrid 1929, pp. 33-35.

Hispania Sacra, LIX

120, julio-diciembre 2007, 427-458, ISSN: 0018-215-X 
ros tiempos se encontrasen ya en gran medida eclipsadas por otras expresiones religiosas, de carácter ceremonial, y contagiadas de elementos propios de la cultura greco-romana. En este sentido, la espiritualidad sencilla y pasional del cristianismo primitivo posiblemente ni siquiera llegó a conocerse en la Península, o en todo caso quedó truncada a partir del siglo III, cuando aquella doctrina asumió en Occidente las formas propias de la religión clásica. Más que degradación espiritual, lo que se produjo entonces (y no en Hispania preferentemente, sino en toda la cristiandad) fue un cambio inevitable en las formas de vida cristiana, pues si la sinceridad y el compromiso eran propios de pequeñas iglesias que ejercían una especie de autocontrol sobre sus fieles, nada de ello era ya posible tras la cristianización superficial, desde mediados del siglo III, de miles, quizá millones de personas. A partir de entonces la necesidad primordial era obviamente asegurar una mínima instrucción catequética a esta multitud de conversos, su obediencia a la reforzada jerarquía clerical y la unidad de todos en reglas elementales de fe y en rituales y festividades que inspiraran el máximo atractivo y fervor popular.

Este proceso, que se prolongó con intensidad desigual durante toda la Antigüedad tardía ${ }^{63}$, no acabó, sin embargo, con toda la espiritualidad o el compromiso típico de los orígenes, como acabamos de ver en el caso extremo de Osio y como puede igualmente apreciarse en el testimonio heroico de algunos mártires hispanos, en particular de aquellos que ofrecen más visos de verosimilitud histórica, como Fructuoso, Augurio y Eulogio en Tarraco o Justa y Rufina en Hispalis $^{64}$. Descalificar el cristianismo hispano por las informaciones que ofrece Cipriano en su carta 67 sobre los obispos apóstatas, es olvidar la reacción de otros obispos y de muchos fieles contra este comportamiento, como bien ilustra la misma epístola del obispo cartaginés. Es cierto que estos fieles parecen ser los perdedores del conflicto, pero su suerte sólo se entiende históricamente por la nueva dimensión pública que, según acabamos de ver, ahora empieza a asumir el cristianismo en todo el Imperio.

El caso de Prisciliano y sus seguidores ilustra bien esta realidad. La espiritualidad que ellos pretenden recuperar recuerda tanto a la de algunas iglesias

${ }^{63}$ Ya Díaz y Díaz observó («Orígenes cristianos de Lugo», en Coloquio int. sobre el milenio de Lugo, Lugo 1977, pp. 237-250, esp. p. 239) que en fechas muy avanzadas del siglo IV el cristianismo se hallaba todavía en una fase muy incipiente de difusión y organización en la provincia romana de $\mathrm{Ga}$ lecia, a la que entonces pertenecía la comunidad de León-Astorga. Y la sucesión regular de obispos en las diversas sedes no se impuso hasta el siglo VI, lo que prueba, según él, la lentitud con que se fue implantando el sistema jerárquico y organizativo de la ortodoxia católica.

${ }^{64}$ Sobre los pormenores de estas y otras actas martiriales y su valor histórico, cfr. C. GARCía RoDRÍGUEZ, El culto de los santos en la España romana y visigoda, Madrid 1966, 316 ss. y P. CASTILLO MALDONADO, Los mártires hispanorromanos y su culto en la Hispania de la Antigüedad Tardía, Granada 1999 , esp. pp. 371 ss. 
primitivas que casi podría afirmarse que ellos fueron los primeros en conocer y practicar el cristianismo ferviente, libre y creativo de los primeros siglos. Su misticismo de inspiración paulina, el acercamiento directo y personal a Dios, su libertad teológica y ritual, el protagonismo relevante de laicos y mujeres... todo ello nos lleva a la fe y la práctica de las primeras comunidades y da la impresión al historiador de que la historia del cristianismo ha ido marcha atrás en Hispania.

Es, claro está, un espejismo, como desvela el simple hecho de que esa espiritualidad arcaica sólo tuviera cabida en el retiro casi clandestino de las villae señoriales, donde una minoría de aristócratas buscaban fortalecer su fe alejados de la mundanidad urbana y de las directrices autoritarias de la jerarquía eclesiástica. Su reconocimiento preferente de los carismas primitivos era en todo incompatible con la autoridad institucional del episcopado. El propio Prisciliano debió de verlo así cuando intentó ganar para los suyos diversas cátedras episcopales y él mismo fue promovido a la de Ávila. Su condena y ejecución en Tréveris por el poder civil -al que también ellos apelaron reiteradamente- prueba hasta qué punto era ya difícil, si no imposible, conciliar la fe primitiva y carismática que predicaban con las estructuras eclesiales y sus compromisos políticos ${ }^{65}$. Así lo confirma, en todo caso, la carta de Consencio a Agustín (Ag. Ep. $11^{*}$ ), ya entrado el siglo $\mathrm{V}$, que nos habla de numerosos clérigos y fieles priscilianistas del Nordeste peninsular, organizados clandestinamente, pero con la complicidad de algunos altos magistrados y potentissimi, e inmersos en una guerra sucia contra otras facciones clericales. La radicalidad del conflicto y sus desenlaces trágicos prueban, en fin, lo mucho que estaba en juego, tanto para la Iglesia como para el Estado.

Que no era esto algo peculiar de Hispania lo demuestra toda nuestra información sobre la Iglesia de la época en las demás provincias del Imperio, en particular Roma y la Galia, donde se constata una situación similar ${ }^{66}$. Que, por contra, era posible en Hispania una vida consagrada al ascetismo y a la práctica de las virtudes propias de cristianismo primitivo, siempre que se aceptara la au-

\footnotetext{
${ }^{65}$ Cfr., entre la ingente bibliografía al respecto, M. C. DíAz y DíAZ, «L'Expansion du Christianisme et les tensions épiscopales dans la Péninsule Ibérique», en Miscellanea Historiae Ecclesiasticae VI,1 (1983), 84-94, y M. V. Escribano PaÑo, «La disputa priscilianista», en R. TeJa (ed.), La Hispania del siglo IV. Administración, economía, sociedad, cristianización, Bari 2002, pp. 205-230. Según Harnack, en Prisciliano encontramos el primer testimonio de un cristianismo independiente en España, y su represión, como la del movimiento monacal, explicaría en gran medida el estado lamentable de la iglesia española a finales del siglo IV (op. cit. p. 539, n. 4 y p. 542).

${ }^{66}$ Baste recordar, a título de ejemplo, la encarnizada lucha por la cátedra episcopal de Roma entre Dámaso y Ursino el año 366, que se saldó con docenas de muertos (Amiano, 27, 3, 14), la implicación de diversos obispos y personajes galos en el certamen priscilianista o, en fin, la corrupción del episcopado en Oriente y Occidente denunciada por el Libellus precum.
}

Hispania Sacra, LIX

120, julio-diciembre 2007, 427-458, ISSN: 0018-215-X 
toridad suprema de la Iglesia, lo testimonia el ejemplo de fieles como Lucinio y Teodora, matrimonio bético que donó gran parte de sus riquezas a pobres e iglesias de todo el orbe, algunas tan alejadas como Jerusalén y Alejandría, siguieron los consejos espirituales de Padres como Jerónimo, llevaron una vida rigurosamente austera, marcada por los ayunos, la castidad y los cilicios, y, en fin, colmaron sus inquietudes intelectuales con lecturas piadosas de autores cristianos. Curiosamente, los testimonios de este género suelen darse no en el pueblo llano, que sigue inmerso en formas religiosas tradicionales, cristianizadas o no, sino en una minoría de aristócratas ilustrados y sensibles, muy distanciados ya de los cultos cívicos tradicionales y expectantes ante las nuevas experiencias religiosas que ofrecía el cristianismo ${ }^{67}$. Una prueba más de que los cambios religiosos de esta época, por revolucionarios que fuesen en el ámbito espiritual, no comportaron transformación social alguna.

Y no podían comportarla -digámoslo como recapitulación y conclusión final- porque, fuera cual fuese el tiempo y la naturaleza del cristianismo que llegó a Hispania, su constitución en una religión y en una Iglesia influyente sólo se verificó, según hemos subrayado, en fechas avanzadas del siglo III, cuando ya había asimilado múltiples elementos cultuales del paganismo y sus adeptos no sintieron su conversión ni vivieron la nueva fe como una negación o ruptura radical con el pasado. Sin el recurso a este profundo sincretismo religioso, hubiera sido inviable la cristianización de amplias masas populares, por superficial que ésta fuera. Incluso así, el fiasco relativo de tamaña empresa se pone de relieve en el escaso apego de innumerables cristianos a sus propios rituales (festividad dominical, pentecostés, asistencia regular a la iglesia...) y el atractivo que, por contra, siguen teniendo para ellos las fiestas paganas (subidas al capitolio, procesiones religiosas, celebraciones de año nuevo.... ${ }^{68}$.

\footnotetext{
${ }^{67}$ De la vida ascética del citado matrimonio nos informan las cartas 71 y 76 de Jerónimo, fechadas en los años 398 y 399 respectivamente. Una vida similar parece llevar el sacerdote ciego Abigao, amigo de los anteriores, al que también escribe Jerónimo una carta de consolación (Ep. 76, del 399). Para más información sobre este tema cfr. J. FoNTAINE, «Valeurs antiques et valeurs chrétiennes dans la spiritualité des grands propiétaires terriens à la fin du IVe siècle occidental», en Epektasis. Mélanges J. Daniélou, Paris 1972, pp. 571-82 (reproducido en J. FonTAINE, Études sur la poésie latine tardive d'Ausone à Prudence, Paris 1980, pp. 241-65); Idem, «Société et culture chrétienne sur l'aire circumpyrénéenne au siècle de Théodose», en Idem, Études sur la poesie latine tardive d'Ausone à Prudence, Paris 1980, 267-82; Idem, Culture et spiritualité en Espagne du IVe au VIIe siècle, Londres 1986; F. J. LomAs, «Secessus in villam: la alternativa pagana al ascetismo cristiano en el círculo de Ausonio», en Antigüedad y cristianismo 7 (1990), 237-286; H. O. MAIER, «Heresy, Households, and the Discipling of Diversity», en V. BuRRUS (ed.), Late Ancient Christianity, Minneapolis 2005, pp. 213-233, esp. 221 ss.

68 Sobre la prolongada pervivencia de prácticas y creencias paganas sigue siendo fundamental S. McKenna, Paganism and pagan Survival in Spain up to the Fall of the Visigothic Kingdom, Washington 1938. Cfr. además la detallada actualización de P. DíAz y J. TorREs, «Pervivencias paganas en el cristianismo hispano (siglos IV-VI)», en AA. VV, Revisiones de Historia Antigua, op. cit. pp. 235-261,
} 
Lo que debiera sorprendernos como historiadores no es esta pervivencia de la tradición entre las masas supuestamente cristianizadas, sino que todavía existiera una minoría lo suficientemente influyente y representativa para dejar numerosos testimonios de su acendrada fe, y que un siglo después, mediada la cuarta centuria, otra minoría, ahora marcadamente aristocrática, redescubriera esa prístina espiritualidad cristiana y se entregara a ella en el retiro de lujosas villae o diera su vida por la recuperación de una Iglesia carismática. Al hombre de hoy, acostumbrado a un cristianismo liberal y confortable (como lo era en cierto modo el politeísmo romano), le es sumamente difícil entender aquella época de verdades absolutas, únicas y vitales para los cristianos más comprometidos y en particular para la cúpula eclesiástica que, como precisó Agustín, tenía en más consideración a la Iglesia que al Evangelio. De ahí que o bien trataran de imponer su ideario por toda clase de medios, la violencia incluida, o bien optaran por cultivar apaciblemente su fe en el desierto o en apartadas $v i$ llae. Todos ellos representan no tanto la suerte de los triunfadores o de los perdedores, aunque lo fueran, como la función primordial que el cristianismo ya desempeñaba como ideología vertebradora de la sociedad y como baluarte espiritual del Estado romano tras la profunda crisis de mediados del siglo III.

y de J. A. JIMÉNEZ SÁNCHEZ, «La legislación civil y eclesiástica concerniente a las supersticiones y a las pervivencias idolátricas en la Hispania de los siglos VI-VII», en Hispania Sacra, 57 (2005), 47-78.

Hispania Sacra, LIX

120, julio-diciembre 2007, 427-458, ISSN: 0018-215-X 